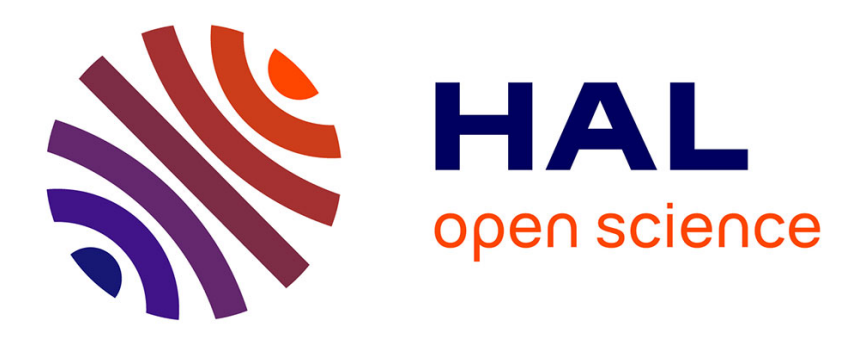

\title{
HEADLESS RELATIVE CLAUSES IN PESH
}

Claudine Chamoreau

\section{- To cite this version:}

Claudine Chamoreau. HEADLESS RELATIVE CLAUSES IN PESH. 2019. halshs-02021454

\section{HAL Id: halshs-02021454 \\ https://shs.hal.science/halshs-02021454}

Preprint submitted on 15 Feb 2019

HAL is a multi-disciplinary open access archive for the deposit and dissemination of scientific research documents, whether they are published or not. The documents may come from teaching and research institutions in France or abroad, or from public or private research centers.
L'archive ouverte pluridisciplinaire HAL, est destinée au dépôt et à la diffusion de documents scientifiques de niveau recherche, publiés ou non, émanant des établissements d'enseignement et de recherche français ou étrangers, des laboratoires publics ou privés. 


\title{
Headless Relative Clauses in Pesh
}

\author{
Claudine Chamoreau \\ CEMCA-SEDYL (CNRS) \\ claudine.chamoreau@cnrs.fr
}

\begin{abstract}
The aim of this study is to describe the two kinds of headless relative clauses that are attested in Pesh, a Chibchan language spoken in Honduras: free relative clauses, which use a wh-word that functions as a relative pronoun to their left edge, and a subordinator to their right edge; and headless relative clauses which lack a $w h$-word, in which a case marker or the topic marker is found to its right edge. The first type is less frequently attested in our natural corpus, although we did find various instances of maximal, existential, and free choice free relative clauses. Each of the constructions is distinguished by features of the wh-word and/or by certain restrictions regarding the tense of the verb in headless relative clauses or the type of verb in matrix clauses. In maximal free relative clauses, only the locatives piah 'where' and pikan 'where, in which direction' can appear. In existential free relative clauses different $w h$-words can be used, but there are restrictions, since only the future tense is used for the predicate in the free relative clause, and the verb in the matrix clause must express existence such as $t \int a$ - 'be, be there, exist, inhabit'. In free choice free relative clauses, different $w h$-words may be used, and these are obligatorily reduplicated. The second type of headless relative clause, the one that does not use a whexpression, behaves like the headed relative clauses that lack a wh-expression. These are much more frequent in the corpus. They are like noun phrases marked at the end by a case marker or the topic maker. The case or topic markers are used for light-headed relative clauses and for almost all types of maximal headless relative clause that have neither a light-head nor $w h$-expression, in contrast to maximal free relatives in which only locative $w h$-words are used.
\end{abstract}

\section{Keywords}

Alignment, case marker, Chibchan, light-headed RC, locative, Pesh, subordinator, topic marker, wh-expression (presence or lack of). 


\section{Introduction and basic features of Pesh}

\subsection{Introduction}

The aim of this study is to describe headless relative clauses in Pesh, a Chibchan language spoken in Honduras. Pesh possesses two main types of headless relative constructions. Free relative clauses are one of these two types. They use a wh-expression (see Section 2) that functions as a relative pronoun to their left edge, and a subordinator to their right edge (see Section 4.1). Pesh exhibits all the three main subtypes of free relative clauses that are attested across languages: maximal, existential, and free choice. Each of these is distinguished by features of the whexpression and/or by certain restrictions regarding the tense of the verb of the free relative clause or the type of verb in the matrix clause. The other type is the headless relative clause that lacks a wh-expression, and where a case marker or the topic marker is found to its right edge (see Section 4.2), as in the case of headed relative clauses that lack $w h$-expressions (see Section 3 ). This second type is used for light-headed relative clauses and for all types of headless maximal relative clause without a $w h$-expression.

\subsection{Pesh, a Chibchan language}

Pesh (Pech, Paya, ISO 639-3pay) is the northernmost of the sixteen living Chibchan languages (Constenla Umaña 2012, Quesada 2007), and the only one spoken in Honduras. It is classified as an isolate within the Chibchan family: it is the sole language that does not belong to Core Chibchan (see figure 1).

Figure 1. Chibchan language family (adapted from Constenla Umaña 2012)

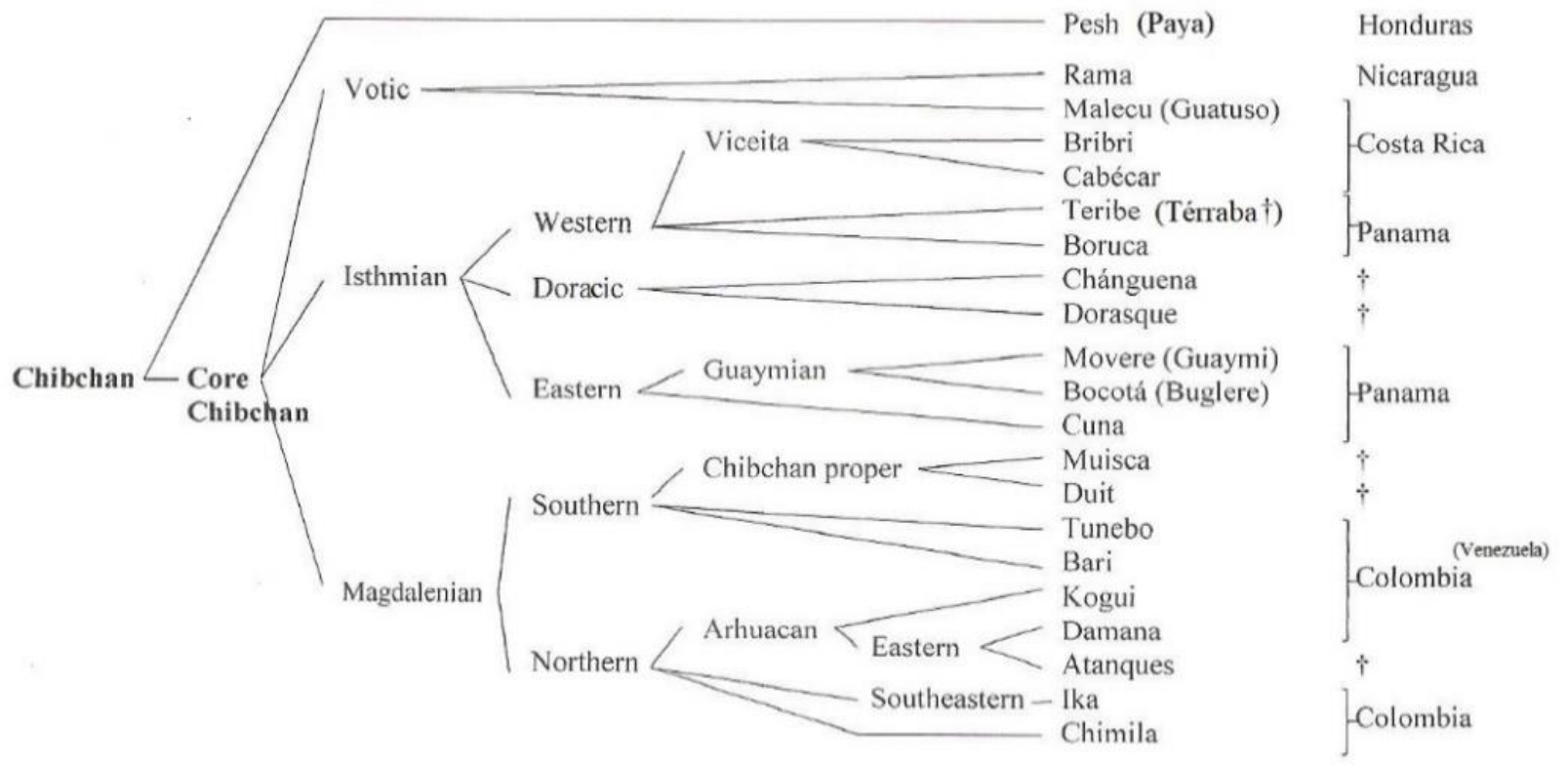

Pesh is endangered: it has roughly 500 speakers, $80 \%$ of whom are over 60 years old. The language is spoken in fourteen villages. Map 1 shows the area where Pesh is spoken; the stars indicate the eight villages where the data used in this research was collected. There are three dialects in total: the Carbon dialect, spoken in Carbon, La Laguna and Agua Amarilla; the Las Marias dialect, which 
is spoken in Las Marias by five speakers; and the Culmi dialect, which is spoken in the remaining ten villages.

Map 1. Pesh in Honduras

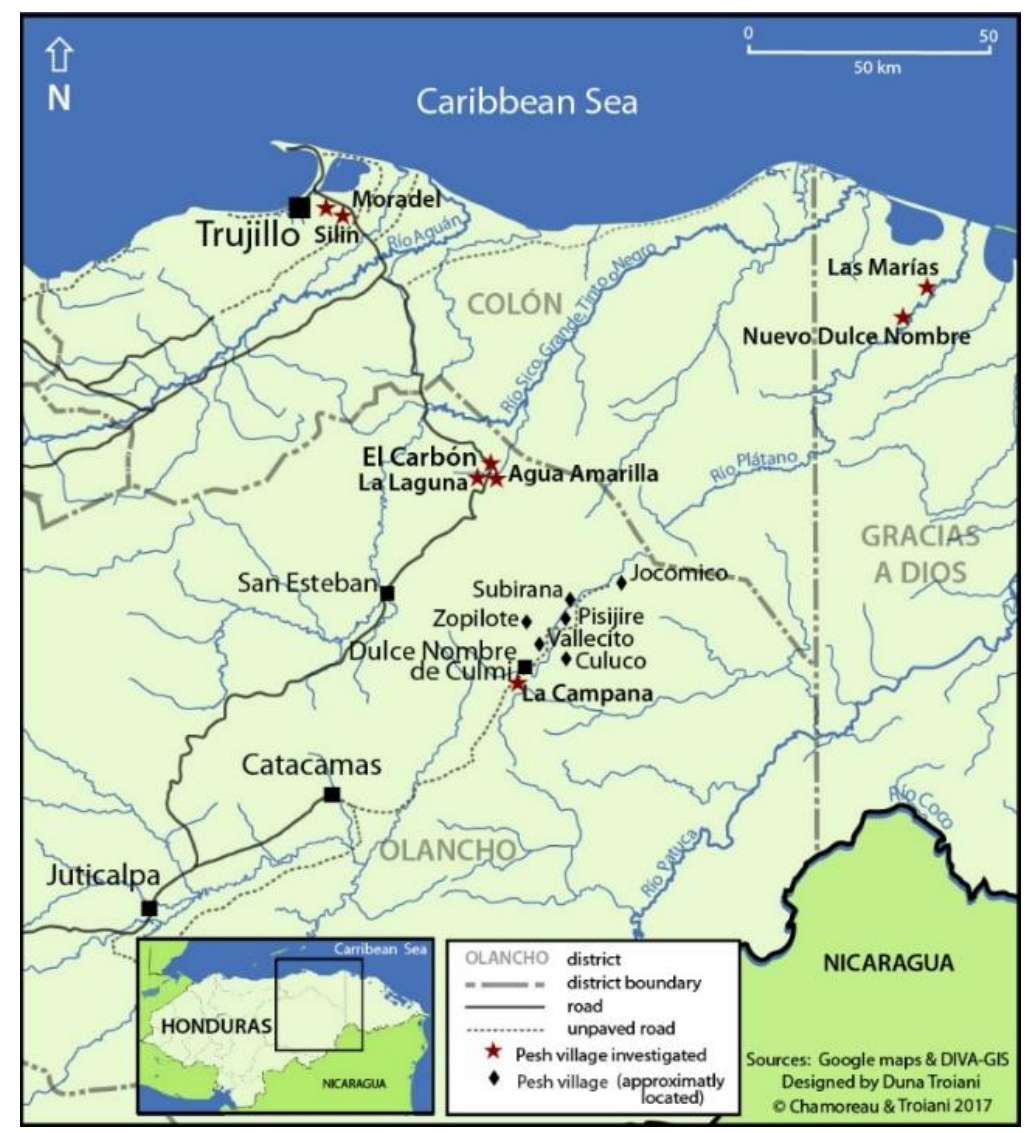

There is little information in the literature on Pesh. An overview dating from 1928 contains a list of Pesh words translated into Spanish (Conzemius 1928). More recently, an incomplete overview of the grammar was published by Holt (1999). The data presented here ${ }^{1}$ were collected as part of the Major Documentation Project "A cross-varietal documentation and description of Pesh, a Chibchan language of Honduras" funded by the Hans Rausing Endangered Languages Programme (HRELP).

\subsection{Basic clause features}

Pesh exhibits the main features associated with verb-final languages. The respective roles of the NPs preceding the verb are indicated by their position, as shown in (1), where the subject wifã $a$ $k a k i$ 'the mother of the fishes' precedes the object $\tilde{a}$ arwã 'that man'. Postpositional phrases (PP) usually appear before the verb, and are marked by an enclitic such as the comitative $=y o$ or the locative $=y \tilde{a}$, as shown in (2).

\footnotetext{
${ }^{1}$ The data consist of 40 hours of narratives, procedural texts, conversations, and discussions during workshops among members of the community, plus data elicited by asking questions about visual stimuli.
} 
(1) wìjà̀ àkákì ã́ ár ${ }^{h}$ wõ kì̀ná

S $\mathrm{O}$

wifã a-kaki ã arwã $\emptyset-k a ?-\varnothing-i=n a$

fish POSS3SG-mother DEM.DIST man OBJ3SG-make-SBJ3SG-PST=REP ${ }^{3}$

'The mother of the fishes did it to that man, they said.' $\{\mathrm{txt}\}^{4}$

(2) tàhnã́ tàrkìyó ás kàpáfkỗíwií

$\begin{array}{ll}\text { LOC COM } & \mathrm{V} \\ \text { taha=yã ta-arki=yo } & \text { as kapaf-k-a-i=wĩ } \\ \text { path=LOC POSS1-man's_brother=COM/INS one } & \text { speak-K-SBJ1SG-PST=long_ago } \\ \text { 'Long ago, I spoke with one of my brothers on the path.' }\{\text { txt }\}\end{array}$

Pesh features a split alignment that is conditioned by the way the arguments are expressed. It has a nominative-accusative alignment for indexing argument verb-agreement affixes, and a differential ergative-absolutive alignment for flagging free NP arguments. Pesh is a double marking language; it can simultaneously exhibit the indexing and flagging of the same participant. Pesh has obligatory verb agreement. The sole argument of an intransitive verb, as in example (2), and the two arguments of a monotransitive verb, as shown in (3) are obligatorily encoded in the verb. A verb has two argument slots. In the case of a ditransitive verb, Pesh exhibits a secundative alignment for indexing: the recipient is the only argument that can be encoded, as shown in $(4,5)$, while the patient cannot (Chamoreau 2017).

Monotransitive verb

(3) ùtfà àkwắsárā àrkàpàrkrà

utfa a-kwãsa=ra a-r-kapar-k-er-wa

fish POSS3SG-spirit=ABS OBJ3SG-APPL.P-thank-K-SBJ3PL-PRS

'They thank the spirit of the fish.' [and no other spirit] $\{\mathrm{txt}\}$

Ditransitive verb

(4) tàtùs tàs tàsùwá wífkrí

ta-tus tas ta-suwa $\quad \varnothing$-wif-k-er-i

POSS1-father PRO1 POSS1-grandmother OBJ3SG-give.OBJ3-K-SBJ3PL-PST

'My parents entrusted me to my grandmother.'

\footnotetext{
${ }^{2}$ In the Pesh examples in this paper, the first line represents a phonetic transcription. The accents indicate types of stress and tone, and the tilde indicates nasalization. The second line gives the phonological transcription without stress/tone marks, the third the morpheme-by-morpheme glosses, and the fourth the English translation.

3 Abbreviations (that are not listed in the Leipzig glossing rules): CONT container (nominalizer); CRT certainty subordinator; DES desiderative; DBT dubitative subordinator; EHRC externally headed relative clauses; FT formative; IHRC internally headed relative clause; K unknown suffix; MC matrix clause; MED medial; MID middle; MIR mirative; NUM numeral; O object; PRO pronoun; PSB possibility; QUANT quantifier; R recipient; RC relative clause; REAS reason; REC recent; REP reportative; S subject; SIM simulative; TEMP/MAN temporal/manner; UNCRT uncertainty subordinator; WH constituent question; $\mathrm{Y} / \mathrm{N}$ polar question.

${ }^{4}\{t x t\}$ means that the example comes from the corpus. For examples that come from elicited data, nothing is indicated.
} 
(5) tàsùwá tã̀ỹhèrî́

ta-suwa ta-ãyh-er-i

POSS1-grandmother OBJ1-give.OBJ1/2-SBJ3PL-PST

'They entrusted my grandmother to me.' $\{\mathrm{txt}\}$

Pesh is a case-marking language with the six phrasal case enclitics listed in (6).

(6) Phrasal case enclitics

=ya Ergative

$=r a$ Absolutive (=ro, a dialectal variation used in the Carbon dialect)

$=y \tilde{a} \quad$ Locative

$=y o \quad$ Comitative/instrumental

$=k a n$ Similative (=ken, a dialectal variation used in the Carbon dialect)

$=r i \quad$ Temporal $/$ manner

Case-marking enclitics are phrase final, as shown in (3) and (7). A differential ergative and absolutive enclitic marking is displayed. Ergative and absolutive markers are triggered by focus (Chamoreau 2018). For flagging, the subject of a transitive verb may be indicated by the ergative marker $=y a$ (7). In contrast, the subject of an intransitive verb, as shown in (8), the object of a monotransitive verb, as shown in $(3,7)$, and both objects in a ditransitive verb may all be marked by the absolutive case marker $=r a$. The marker $=r a$ is never used with the subject of an intransitive verb in the Culmi dialect. In a ditransitive verb, Pesh exhibits a neutral alignment for flagging.

(7) tíkíí tó?mànìhyá ấkồr èrò

$\begin{array}{lllll}\emptyset \text {-ti-k-i-i } & \text { to? } & \text { manih=ya } & \tilde{\mathbf{a}} & \text { kõre=ro } \\ \text { OBJ3SG-Say-K-SBJ3SG-PST } & \text { DEM.MED } & \text { rabbit=ERG } & \text { DEM.DIST } & \text { uncle=AB }\end{array}$

'The rabbit said [something] to that uncle.' $\{\mathrm{txt}\}$

(8) wắtárá tòkkí

wãta=ra tok-k- $\emptyset-\mathrm{i}$

shaman=ABS enter-K-SBJ3SG-PST

'The shaman got in.' $\{\mathrm{txt}\}$

Tense is obligatory on finite verbs. Four tense markers exist: $i$ / $r i$ 'PST' (8), $f i$ 'PST.REC' (9), $w a$ 'PRS' (3), and pi 'FUT' (10a). The future tense can display potential values and is also used in conjunction with past (10b) and recent past (10c).

(9) kwákwánàrí kápàjkúfí

kwakwana=ri kapaf-k-u-ji

hardness $=$ TEMP/MAN speak-K-SBJ3SG-PST.REC

'He spoke with severity.' $\quad\{\mathrm{txt}\}$

(10) a. àsòrò ừ?mústépí

aso=ro $\quad \tilde{u}$ ?-mus-t- $\varnothing$-pi

water=ABS CAUS-fill-DUR-SBJ3SG-FUT

'The water will rise.' $\{\mathrm{txt}\}$ 
b. kà?párí

$\emptyset$-ka?-pa-ri

OBJ3SG-make-SBJ1sG.FUT-PST

'I was going to do it.' \{txt c. nồpííi

nã-u-pi-ji

go-SBJ2-FUT-REC.PST

'You were going to go (recently).' $\quad\{\mathrm{txt}\}$

\subsection{The noun phrase}

A simplified template for the NP is provided in (11):

$$
\text { DEM }+ \text { POSS-ROOT-INDF.ART } / \text { PL.POSS }+ \text { ADJ }+ \text { NUM } / \text { QUANT }+=\text { CASE }+=\text { TOP } / \text { FOC }
$$

The properties of the NP are those typically associated with head-final characteristics. The possessor occurs before the possessum, that is, in an NP the modifier is preposed to the head (12a). The indefinite article $-s$ is always postposed, as shown in (12b), as are numerals, shown in (13).

Possessor - Possessum (modifier - head):

(12) a. ta-ye? a-wãri POSS1-small POSS3SG-pig

'My son's pig' (lit. my son, his pig) $\quad\{$ txt $\}$ b. korta-s woman-INDF.ART 'a woman' $\{t x t\}$

(13) tó? íspáràh àmùktá tềnáhpó:kyó kàtù̀jkáwá

to? isparah amukta tẽnah po:k=yo katũf-k-a-wa

DEM.MED machete rotten heavy two=COM/INS work-K-SBJ1SG-PRS

'I worked with these two rotten, heavy machetes.' $\{\mathrm{txt}\}$

Demonstratives indicate definiteness, such as to? (13), while indefinite determiners (quantifiers) and indefinite articles such as $-s$ express indefiniteness (12b). Nevertheless, bare NPs are frequently used. Usually the context is sufficient to encode definiteness (14) and indefiniteness (15). In (14) the noun takaskro constitutes the definite NP 'the sisimite', and in (15) the noun arwã constitutes the indefinite NP 'a man'.

(14) î́kầkếs tàkáskrò kàù̀trốPtíhéré

$\tilde{i}=$ kan akẽs takaskro ka-ũtro?- $\varnothing-t \mathrm{~V}-\mathrm{i}=$ here

DEM.PROX=SIM thus sisimite OBJ3PL-kidnap-SBJ3SG-NEG-PST=MIR

'Thus, the sisimite kidnapped them.' $\{\mathrm{txt}\}$

(15) krís árwắ tjìrí;

kris arwã tfa-i-ri

time man be_there-SBJ3SG-PST

'Some time ago, there was a man.' $\{$ txt $\}$

The three demonstrative pronouns, i.e. proximal $\tilde{\imath}$, medial to? (tu?) and distal $\tilde{a}(t a)$, play an important role for indefinite pronouns and $w h$-words (Table 1 ).

\footnotetext{
${ }^{5}$ The 'Sismite' is a mythological character in Central America. He is described as a hairy monster with manlike
} characteristics and feet that are turned backwards, who kidnaps women to take them into his cave. 


\section{Table 1. Demonstrative pronouns and determiners}

\begin{tabular}{|c|c|}
\hline Proximal & $\tilde{l}$ \\
\hline Medial & to? / tu? (dialectal variant) \\
\hline Distal & $\tilde{a} / t a$ (dialectal variant) \\
\hline
\end{tabular}

Demonstratives may be pronouns and determiners. Example (16a) illustrates their use as pronouns, where they can optionally be marked by the topic marker (16b; see Section 1.5) or a case marker (16c; see Section 1.3). As a determiner, they cannot be marked by a case marker or a topic marker. If such markers are used in the NP they will be phrase final, as shown in $(7,13,16 \mathrm{~b})$.

Demonstrative pronoun

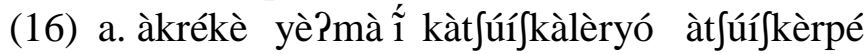

akreke ye?=ma $\tilde{\mathbf{i}}$ ka-tfuif-k-a-ler=yo

but $\quad$ small=TOP DEM.PROX APPL.R-learn-K-NMLZ-PL=COM/INS

a-t $\int u i \int-k-e r-p i$

OBJ3SG-learn-K-SBJ3PL-FUT

'But the young will learn this (one) with the teachers.' $\{$ txt $\}$

b. tó $=$ mà ã́yèkórtàrá éhkíí, kwã̀sà wárkì pàkérpírírás

\begin{tabular}{|c|c|c|c|c|}
\hline to? $=\mathrm{ma}$ & ye & korta $=\mathrm{ra}$ & eh-k-i-i & warki \\
\hline $\begin{array}{l}\text { DEM.MED=TOP } \\
\emptyset \text {-pa-k-er-pi-ri }\end{array}$ & $\begin{aligned} & \text { DEM.DIST small } \\
= & \text { ras }\end{aligned}$ & woman=ABS & treat-K-SBJ3SG-PST spirit & bad \\
\hline
\end{tabular}

'This one treated this young girl because the bad spirits were going to take her.' $\{$ txt $\}$

c. táyá takìusí

ta=ya ta-ka-u-si

DEM.DIST=ERG OBJ1-make-SBJ3SG-PST.REC

'That one struck me.' $\{$ txt $\}$

The proximal demonstrative pronoun $\tilde{l}$ and the distal demonstrative pronoun $t a$ are also used as indefinite pronouns. The non-human indefinite pronoun is $\tilde{\imath}=n a$ 'something', as seen in (17a), with the marker $=n a$ expressing indefiniteness. The human indefinite pronoun is as=na (or less frequently as alone), that is, the numeral as 'one' and the marker of indefiniteness, shown in (17b).

(17) a. î̀ktã̄mã̀ î́nà úptfàhít fí

îkata=ma $\tilde{\mathbf{i}}=\mathbf{n a} \quad \emptyset$-u?t $\int \mathrm{ah}-\mathrm{i}-\mathrm{t} \int \mathrm{i}$

nOw=TOP DEM.PROX=INDF OBJ3SG-Sell-SBJ2-PST.REC

'Did you sell something today?' $\{\mathrm{txt}\}$

b. ásnà kà?otfúífkó tfằắrí

as=na ka?o-t $\int u i \int-k o \quad \emptyset$-t $\int \tilde{a}$-a-ri

one $=$ INDF house-learn-CONT OBJ3SG-ver-SBJ1SG-PST

'I saw someone in the school.' $\quad\{$ txt $\}$ 
The non-human indefinite pronoun for 'nothing' is $\tilde{l}=r i=n a$, that is, the proximal pronoun $\tilde{i}$, the coordinator $=r i$ and the indefinite marker $=n a$; an example is given in (18a). The human indefinite pronoun for 'no one, nobody' is $a s=n a=r i=n a$, shown in (18b), or $t a=y a=r i=n a$, as shown in (18c). The former is used as the subject of an intransitive verb and the object of a transitive verb; the latter is used as the subject of a transitive verb. In these clauses, the verb always contains the negative marker, shown in (18b); its absence is ungrammatical, as seen in (18d), and it cannot be used to mean 'someone' either.

(18) a. Î́rínà úPtfâhtát fí

$\tilde{\mathbf{i}}=\mathbf{r i}=\mathbf{n a} \quad \emptyset$-uPt $\int \mathrm{ah}-\mathrm{a}-\mathrm{tV}-\mathrm{t} \mathrm{j}$

DEM.PROX=COORD $=$ INDF OBJ3SG-sell-SBJ1SG-NEG-PST.REC

'I sold nothing' $\quad\{\mathrm{txt}\}$ (lit. 'I didn't sell nothing.')

b. ásnàrínà àkàììjtèrí

$\begin{array}{ll}\mathbf{a s}=\mathbf{n a}=\mathbf{r i}=\mathbf{n a} & \text { a-ka-iti } \mathbf{a}-\text {-er-tV-ri } \\ \text { one }=\mathrm{INDF}=\mathrm{COORD}=\mathrm{INDF} & \text { REFL/RECP-APPL.R-steal-SBJ3PL-NEG-PST }\end{array}$

'They stole no one.' $\{$ txt $\}$ (lit. 'They didn't steal no one.')

c. î̀ktã̃mã̀ pàtàòryàrî́mã̀: táyàrínà kìtwố

îkita $=$ ma pa-ta $\quad$ ta $=\mathbf{y a}=\mathbf{r i}=\mathbf{n}=\mathbf{n a}$

nOw $=$ TOP INCL-POSS 1 culture $=$ TEMP/MAN=TOP DEM.DIST $=E R G=C O O R D=I N D F$

$\emptyset$-ka-i-tV-wa

OBJ3SG-make-SBJ3SG-NEG-PRS

'Nowadays, no one makes (anything) by means of our culture.' $\{\mathrm{txt}\}$ (lit. 'Nowadays, no one doesn't make (anything) by means of our culture.'

d. *ásnàrínà àkàìîjkèrí

*as $=\mathbf{n a}=\mathbf{r i}=\mathbf{n a} \quad$ a-ka-itif-k-er-ri

*one $=\mathrm{INDF}=\mathrm{COORD}=\mathrm{INDF} \quad$ REFL/RECP-APPL.R-steal-K-SBJ3PL-PST

Intended reading: 'They stole no one.' or 'They stole someone.'

\subsection{The predicate enclitic markers}

Five predicate enclitics among those that are attested in Pesh are particularly relevant for this study; these are shown in Table 2 below. Two of them mark matrix interrogative clauses, while the other three mark subordinate clauses. They always occur at the right-edge of the predicate, and none can co-occur with any of the others. 
Table 2. Relevant predicate enclitic markers in Pesh

\begin{tabular}{|l|l|l|}
\hline \multicolumn{1}{|c|}{ Marker } & \multicolumn{1}{|c|}{ Marker Name } & \multicolumn{1}{c|}{ Constructions where the marker occurs } \\
\hline$=s a$ & wh-interrogative marker & matrix $w h$-interrogative clause \\
\hline$=r e ?$ & polar interrogative marker & matrix polar interrogative clause \\
\hline$=k a n /=k e n^{6}$ & dubitative marker & \\
\hline$=s r i$ & uncertainty marker & \multirow{2}{*}{ embedded declarative/interrogative/relative clauses } \\
\hline$=m a$ & certainty marker & \\
\hline
\end{tabular}

Although the predicate is usually in clause-final position, when it is followed by some other constituent, the enclitic still combines with the predicate, as shown in (19b). I discuss each enclitic in turn below.

$W h$-interrogative marker. The enclitic $=s a$ characterizes matrix $w h$-interrogative clauses, as shown in (19a-b). A comparison of (16c) and (19a) shows that only the presence of $=s a$ distinguishes the two clauses and allows the interpretation of (19a) as a content interrogation and of $t a=y a$ 'DEM.DIST=ERG' as a $w h$-word.

(19) a. táyá pìkìusísà

ta $=\mathbf{y a} \quad$ pi-ka-u-si=sa

DEM.DIST=ERG OBJ2-make-SBJ3SG-PST.REC $=$ WH

'Who struck you?' $\{$ txt $\}$

b. tárá kàkàpéPkísísà ùtfâ

$\begin{array}{lll}\text { ta=ra } & \text { ka-ka-peP-k-i-si=sa } & \text { ut } \int \mathrm{a} \\ \text { DEM.DIST=ABS } & \text { OBJ3PL-APPL.R-bring-SBJ2-PST.REC=WH } & \text { fish } \\ \text { 'For whom (pl) did you (sg) bring the fish?' }\{\text { txt }\} & \end{array}$

Polar interrogative marker. The enclitic $=r e$ ? characterizes matrix polar interrogative clauses in the Carbon dialect (20a). In the Culmi dialect, however, matrix polar interrogative clauses are not marked with any special enclitic and are identical to declarative clauses in form. A final higher pitch distinguishes polar interrogative clauses, shown in (17a), from declarative clauses. Interestingly, $=r e$ ? is used to trigger a doubt about whether an event will happen or has happened in the Culmi dialect; this is shown in (20b).

(20) a. nềríré?

nã-er-ri=re?

go-SBJ3PL-PST $=Y / N$

'Did they go?' $\{\mathrm{txt}\}$

${ }^{6}=$ ken in the Carbon dialect. 
b. tè?nềrítípíríré?

te?-nã-i-tV-pi-ri=re?

come-go-SBJ3SG-NEG-FUT-PST $=\mathrm{Y} / \mathrm{N}$

'He was going to come (but) did he come or not?' $\{\mathrm{txt}\}$

The remaining three enclitics mark different degrees of probability or possibility that the event described in the embedded clause in which they occur will happen or has happened (Bybee 1985: 178-180).

Dubitative marker. The use of $=k a n /=k e n$ expresses doubt or weak possibility that the event described in the clause may occur or may have occurred ('irrealis'). For instance, in (21), the speakers do not know whether they can take the grandmother somewhere, or how to take her there.

(21) î́kànkà pàbèrpékén ừntãkàtfúà

$\begin{array}{ll}{[\tilde{1}=\text { kan-ka-a }} & \emptyset \text {-pa-ber-pe=ken }] \\ \text { DEM.PROX=SIM-make-SBJ1 } & \text { OBJ3SG-take-SBJ1PL.EXCL-FUT=DBT } \\ \text { ũn-ta-ka-t } \int a-\emptyset \text {-wa } & \\ \text { EXCL-OBJ1-APPL.R-be_there-SBJ3SG-PRS }\end{array}$

'[It is not sure whether] we can [and we are not sure how to] take her' $\quad$ txt $\}$

The dubitative enclitic $=k a n$ is related to the similative case maker $=k a n$ used in a NP (see Section 1.3). Cross-linguistically, the relation between similarity and irrealis or doubt is well-known (Creissels 2017: 79-89).

Uncertainty marker. The enclitic $=$ sri signals uncertainty about whether the event will happen or has happened. Usually the speaker knows various conditions that make it probable, but uncertainty still exists. In (22), the speaker knows how to take the grandmother; the uncertainty resides in whether or not they will take her. Example (22) can be compared to example (21) with the dubitative enclitic $=k a n$.

(22) îkànkà pàbèrpésrí û̀ntãkàtfúà

\begin{tabular}{|c|c|}
\hline$[\tilde{i}=k a n-k a-a$ & $\emptyset$-pa-ber-pe=sri] \\
\hline $\begin{array}{l}\text { DEM.PROX=SIM-make-SBJ1 } \\
\text { ũn-ta-ka-tfa- } \emptyset \text {-wa }\end{array}$ & OBJ3SG-take-SBJ1PL.EXCL-FUT=UNCRT \\
\hline
\end{tabular}

'We may have a way to take her'

In (23), the speaker knows that he will eat but he doesn't know if the person he is speaking with will agree to cook something for him. The bracketed embedded clause in (23) is a free choice free relative clause, and the free choice expression that is translated with whatever results from the repetition of the demonstrative proximal. We will discuss free choice free relative clauses and their wh-expressions in Section 4.1.3. 
(23) î́rírî́ tàkàtùhúpísrí ã́pã́hã́?

$\begin{array}{lll}{[\tilde{i}=\mathrm{ra}} & \tilde{\mathrm{i}}=\mathrm{ra} & \text { ta-ka-tuh-u-pi=sri }] \\ \text { DEM.PROX=ABS } & \text { DEM.PROX=ABS } & \text { OBJ1-APPL.R-cook-SBJ2-FUT=UNCRT } \\ \emptyset \text {-ã-pa=hã? } & \\ \text { OBJ3SG-eat-SBJ1sG.FUT=FOC } \\ \text { 'I will eat whatever you may cook for me.' }\end{array}$

Certainty marker. The use of the enclitic $=m a$ at the end of a predicate indicates that the event has happened or is in the process of happening. In (24), this is an affirmation that the narrator and his brothers know how to take the grandmother to hospital. Example (24) can be compared with (21), which contains the dubitative marker =kan, and with example (22), which contains the uncertainty marker $=$ sri.

(24) îkànkà pàbèrpémà ừntãkàtfúà

\begin{tabular}{|c|c|}
\hline$[\tilde{1}=\mathrm{kan}-\mathrm{ka}-\mathrm{a}$ & $\emptyset$-pa-ber-pe $=\mathbf{m a}]$ \\
\hline $\begin{array}{l}\text { DEM.PROX=SIM-make-SBJ1 } \\
\text { ũn-ta-ka-t } \int a-\varnothing \text {-wa }\end{array}$ & OBJ3SG-take-SBJ1PL.EXCL-FUT=CRT \\
\hline
\end{tabular}

In (25), the meal is already prepared and the narrator is about to eat it. The certainty marker $=m a$ corresponds to a realis interpretation. Compare (25) with (23), where the uncertainty marker $=s r i$ is used.

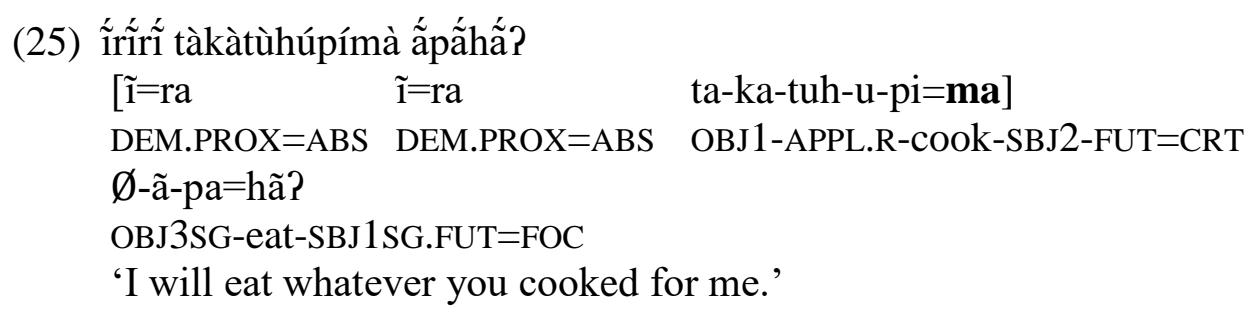

The certainty marker $=m a$ is related to the topic marker $=m a$ in an NP. Topic and certainty markers share the same characteristic of introducing a given or actualized participant or event. The topic marker is optional and usually correlates with thematic discontinuity or referent complexity, that is, with the need to encode the topic to maintain discourse coherence (Chamoreau forthcoming.a). The NP that contains the topic is usually preposed, as in (26). When the enclitic =ma marks a subject or object NP, it is impossible to encode the ergative or absolutive case marker. The topic marker $=m a$ is used alone with the constituent that expresses an argument (again, shown in (26)).

(26) tàsùwámà ấkã́n ờ:nínà wíhnà yó

$\begin{array}{llll}\text { ta-suwa=ma } & \tilde{a}=\mathrm{kan} & \tilde{\mathrm{o}}-\mathrm{n}-\emptyset \text { - } \mathrm{i}=\mathrm{na} & \text { wihna=yo } \\ \text { POSS1-grandmother=TOP } & \text { DEM.DIST=SIM } & \text { sleep-DUR-SBJ3SG-PST=REP } & \text { shaman=COM/INS } \\ \text { 'They said that my grandmother died like this, by the shaman.' }\{\text { txt }\}\end{array}$




\section{Wh-interrogative clauses}

This section introduces $w h$-interrogative clauses in Pesh and their $w h$-expressions, which will be relevant for our discussion of free relative clauses in Section 4.1. Matrix $w h$-interrogative clauses are presented first, followed by embedded $w h$-interrogative clauses. The two constructions exhibit an important difference, which will be important for free relative clauses as well.

Pesh forms wh-expressions from five different sources, as shown in (27):

(27) 1. ta DEM.DIST for 'who' [+ HUM]

2. ĩ DEM.PROX for 'what, how, why, when' [- HUM]

3. ã DEM.DIST for 'when'

4. the verb 'place, put down' $p i$ - for 'where, which'

5. pif for 'how many, how much'

The complete list of $w h$-expressions in Pesh is given in Table 3.

Table 3. Paradigm of $w h$-expressions in Pesh

\begin{tabular}{|c|c|c|c|}
\hline Basic meaning & Further specifications & Pesh wh- & Glosses \\
\hline \multirow[t]{5}{*}{ WHO } & 'who' + Vtr & $t a=y a$ & DEM.DIST=ERG \\
\hline & $\begin{array}{l}\text { ‘who' }+V_{\text {intr }} \\
\text { ‘to who’ }+V_{\text {tr }}\end{array}$ & $t a=r a$ & DEM.DIST $=\mathrm{ABS}$ \\
\hline & 'with who' & $t a=y o$ & DEM.DIST=COM/INS \\
\hline & 'in whose house' & $t a=y \tilde{a}$ & DEM.DIST=LOC \\
\hline & 'whose'+ N & ta-?eh & DEM.DIST=FT.POSS.PRO \\
\hline \multirow[t]{3}{*}{ WHAT } & 'what' $+V_{\text {tr }}$ & $\tilde{l}=y a$ & DEM.PROX=ERG \\
\hline & $\begin{array}{l}\text { 'what' }+V_{\text {intr }} \\
\text { 'to what' }+V_{\text {tr }}\end{array}$ & $\tilde{\imath}=r a$ & DEM.PROX=ABS \\
\hline & 'with what' & $\tilde{l}=y o$ & DEM.PROX=COM/INS \\
\hline \multirow[t]{2}{*}{ WHERE } & & $p i-a h$ & place-NMLZ \\
\hline & & $p i=k a n$ & place $=$ SIM \\
\hline \multirow[t]{3}{*}{ WHEN } & 'when' (past) & $\tilde{l}=k a w a r$ & DEM.PROX $=$ ? \\
\hline & 'when' (present/future) & $\tilde{a}=h \tilde{\imath}$ & DEM.DIST=? \\
\hline & 'at what time' & $\tilde{a}-p e=r i$ & DEM.DIST-TIMES=TEMP/MAN \\
\hline HOW & & $\tilde{l}=k a n(-k a)$ & DEM.PROX=SIM-('make') \\
\hline WHY & & $\tilde{l}=r e \int$ & DEM.PROX=REAS \\
\hline WHAT/WHICH & & $p i-a h=r a$ & place-NMLZ=ABS \\
\hline $\begin{array}{l}\text { HOW MUCH/ } \\
\text { HOW MANY }\end{array}$ & & pif & \\
\hline
\end{tabular}

To form $w h$-expressions, the case markers are obligatory with the demonstratives, as already shown in (19a-b), and with the verb pi-, as shown in (28). For some $w h$-expressions, instead of a case enclitic, a possessive or a nominalizer, as shown in (29) and (30) respectively, is used. This feature is opposite to the optionality of case marker presence when the demonstratives function as pronouns in an NP (see Section 1.4). A wh-expression must occur in clause-initial position, never 
in situ. The predicate usually occurs at the right edge, and is obligatory marked by the whinterrogative marker $=s a$. For information structure some adverbs may appear after the predicate, as shown in (30).

(28) pìáhrà kúhísísà

$\begin{array}{ll}\text { pi-ah=ra } & \emptyset \text {-kuh-i-si=sa } \\ \text { place-NMLZ=ABS } & \text { OBJ3SG-buy-SBJ2-PST.REC=WH }\end{array}$

'Which one did you buy?'

(29) tá?à tùsrà wàháyã́ nẽ̀ísà

ta-?eh tus=ra waha=yã nã- $\varnothing-\mathrm{i}=\mathbf{s a}$

DEM.DIST-FT.POSS.PRO father=ABS hill=LOC go-SBJ3SG-PST=WH

'Whose father went to the hill?' ('the father of whom') $\{\mathrm{txt}\}$

(30) pyăh nồpísà tfá

$\begin{array}{lll}\text { pi-ah } & \text { nã-u-pi=sa } & \text { t } \mathfrak{a} \\ \text { place-NMLZ } & \text { go-SBJ2-FUT=wH } & \text { tomorrow } \\ \text { 'Where will } & \text { tougo }\end{array}$

'Where will you go tomorrow?' $\{\mathrm{txt}\}$

Embedded $w h$-interrogative clauses require a $w h$-expression at the left edge of the clause, like matrix $w h$-interrogative clauses. But the two types of clauses differ: embedded $w h$-interrogative clauses need one of the three subordinators we discuss in Section 1.5.2: the uncertainty marker =sri (31), the dubitative =kan (32) and the certainty marker =ma (33). Embedded interrogative clauses always follow their matrix clause.

(31) àhírtáwá táyó tè?kúrísrí

a-hir-a-tV-wa [ta=yo te?-k-u-ri=sri]

OBJ3SG-know-SBJ1SG-NEG-PRS DEM.DIST=COM/INS come-K-SBJ2-PST=UNCRT

'I don't know who you should have come with.' $\{$ txt $\}$

(32) àhírífkíwá ã́hì̀ àtfằmìrmkánwã́?

a-hir-i $\int-k-i-w a \quad\left[\tilde{a}=h \tilde{i} \quad\right.$ a-t $\left.\int \tilde{a}-b e r-p i=k a n=w a ̃ ?^{7}\right]$

OBJ3SG-know-DES-K-SBJ3SG-PRS DEM.DIST=? REFL/RECP-See-SBJ1PL-FUT=DBT=PSB

'He wants to know when we may be able to see each other.' $\{$ txt $\}$

(33) jầhrî́ ĩ́ná kàt fúíjkámà

$\begin{array}{lll}\emptyset \text {-yẽh-a-ri } & {[\tilde{\mathbf{i}=\mathbf{y}}} & \left.\text { ka-t } \int u i f-k-\emptyset-w a=m a\right] \\ \text { OBJ3SG-say-SBJ1sG-PST } & \text { DEM.PROX=ERG } & \text { APPL.R-learn-K-SBJ3SG-PRS=CRT }\end{array}$

'I told him who teaches.' $\quad\{\mathrm{txt}\}$

\section{Headed relative clauses}

This section introduces the three main types of restrictive headed relative clauses that are found in Pesh. The crucial factor that distinguishes them is the syntactic role of the head noun within the

\footnotetext{
${ }^{7}$ The co-occurrence of the subordinator $=k a n$ and the marker of weak possibility $=w \tilde{a} ?$ expresses that there is a doubt and a weak possibility that the event described in the clause will take place or has taken place.
} 
relative clause (RC) (Chamoreau forthcoming.b). The first type occurs when the head noun is a genitive or an argument in the RC. The enclitic that occurs at the end of the RC, that may be a case marker or the topic marker, corresponds to the syntactic role of the noun in the matrix clause (MC). In (34), the accusative ${ }^{8}=\mathrm{ra}$ marks the fact that the noun korta 'the woman' is the primary object in the MC regardless of its role in the RC. In (34), the noun korta 'the woman' is the subject of the RC. This behavior coincides with Comrie's (1989 [1981]:145) description of an internally headed relative clause.

\section{(34) tàsmà [kàpàn kàpàn kórtà tà-yè? kàtjềmirà] wífkárí \\ tas=ma [ kapani kapani korta ta-ye? \\ PRO1=TOP morning morning woman POSS1-small \\ $\emptyset$-ka-t $\left.\int a ̃-\varnothing-p i\right]_{R C}=$ ra $\quad$-wi $\quad$-k-a-ri \\ OBJ3SG-APPL.R-see-SBJ3SG-FUT=ACC OBJ3SG-give.OBJ3-K-SBJ1SG-PST \\ 'I entrusted him to the woman who will take care of my son every morning.' $\{\mathrm{txt}\}$}

The second type of relativization is used when the head noun has a non-argumental, non-genitive, peripheral (oblique or adjunct) role in the RC. The case marker that obligatorily occurs at the end of the RC corresponds to the syntactic role of the noun in the RC. In (34), the comitative/instrumental =yo indicates that the noun kukarska 'the hoe' is the instrument in the RC regardless of its role in the matrix clause. In (35) the noun kukarska 'the hoe' is the object in the matrix clause. The noun that functions as the head of the RC occurs outside of it, being represented in the RC by a gap marked by _ in (35). The whole construction is an externally headed relative clause.

(35) [kúkàrskà yè?há tàkíyó] úhàrí

$\begin{array}{lll}{[\text { kukarska } \quad[\text { ye?-ha }} & \text { ta-ka- } \varnothing-\mathrm{i}=\mathbf{y o}]]_{\mathrm{RC}} & \emptyset \text {-uh-a-ri } \\ \text { hoe } & \text { oBJ1-hit-SBJ3SG-PST=COM/INS } & \text { OBJ3SG-hide-SBJ1SG-PST } \\ \text { 'I hid the hoe with which the small boy hit me.' }\{\text { txt }\} & \end{array}$

The third type of relativization is observed when the head has the role of a locative adjunct in the $\mathrm{RC}$, regardless of its role in the matrix clause. In this case, a locative $w h$-expression can introduce the RC and functions as a relative marker. In (36) the noun taha 'the path' is the object in the matrix clause. The noun that functions as the head of the RC occurs outside of it, as in (36) where taha 'the path' is referred to inside the RC by means of the clause-initial locative wh-expression pikan 'where, in which direction', which shows its semantic role within the RC. The movement of the constituent indicating the locative role to the fronting position leaves a trace marked by $t$ in the original position (Comrie 1998:64-67). The relative clause is obligatorily marked by a subordinator encliticized at the end of the verb, for example, with the uncertainty subordinator $=s r i$ (36) or the dubitative subordinator =kan (37). When the head noun is locative in the RC and the matrix clause, it is flagged by the locative case (37). This feature distinguishes this kind of headed relative clause from those without a $w h$-expression, where it is impossible for the case to mark the head noun (35). The wh-expressions piah 'where' (37) and pikan 'where, in which direction' (36) are the only two that are used in headed relative clauses.

\footnotetext{
${ }^{8}$ In headed relative clauses, the alignment is subject-accusative (Chamoreau forthcoming.b). The alignment is not nominative-accusative as the marker $=m a$ is used for the subject and the genitive, thus it indicates a syntactic role and not a morphological marker.
} 
(36) tàhà pìkàn nè̀rísrí tjã̀árí

$\begin{array}{lll}{\left[[\text { taha }]_{N}[\mathbf{p i}=\mathbf{k a n}\right.} & t \quad \text { nã-er-ri=sri }]]_{\mathrm{RC}} & \emptyset \text {-t } \int \tilde{a}-\mathrm{a}-\mathrm{ri} \\ \text { path place=SIM } & \text { go-SBJ3PL-PST=UNCRT } & \text { OBJ3SG-See-SBJ1SG-PST } \\ \text { 'I saw the path that they went toward.' }\{\text { txt }\} & \end{array}$

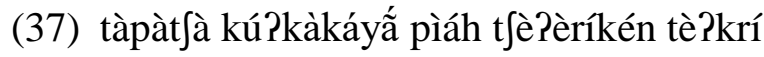

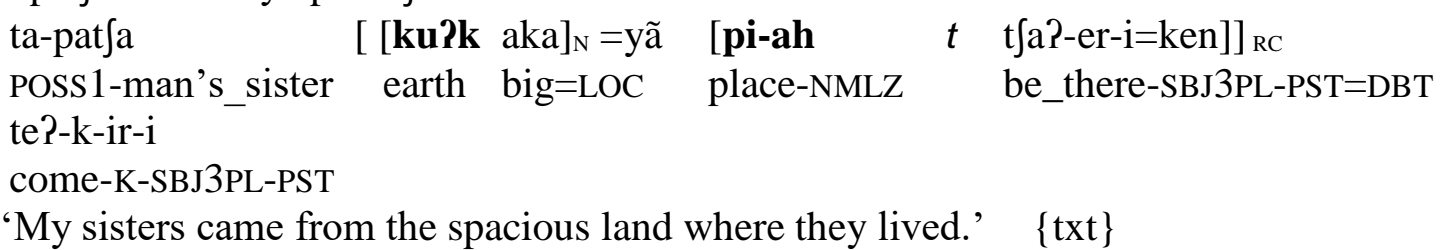

In the first two kinds of headed relative clauses, the marker that obligatorily occurs at the end of the relative clause is a case marker or the topic enclitic prototypically used at the end of noun and postpositional phrases. In contrast, the third kind of headed relative clause is marked by the clauseinitial locative $w h$-expression and a clause final subordinator. The head noun may be marked by the locative case marker. This is impossible in headed relative clauses that lack $w h$-words, where the case marker always occurs clause finally.

The distribution of the three kinds of restrictive headed relative clause thus clearly responds to the accessibility restrictions on specific roles summarized in Table 4: argument and genitive with internally headed relative clauses, oblique and adjunct (comitative, instrumental, locative, and object of comparison) with externally headed relative clauses, and locative with relative clauses with a wh-expression.

Table 4. Accessibility to different roles

\begin{tabular}{lcccccc}
\hline Strategy & SBJ & $\begin{array}{c}\text { OBJ } \\
\text { (primary/secondary) }\end{array}$ & GEN & INS & COM & LOC \\
\hline IHRC & $\sqrt{ }$ & $\sqrt{ }$ & $\sqrt{ }$ & $*$ & $*$ & $*$ \\
EHRC & $*$ & $*$ & $*$ & $\sqrt{ }$ & $\sqrt{ }$ & $\sqrt{ }$ \\
RC with a locative & $*$ & $*$ & $*$ & $*$ & $*$ & $\sqrt{ }$ \\
wh-expression & & & & & & \\
\hline
\end{tabular}

Note. $\sqrt{ }$ : acceptable; *: not acceptable

\section{Headless relative clauses}

This section describes the two main types of headless relative clause in Pesh and the various subtypes. Section 4.1 introduces the first type, i.e. the free relative clause, which is characterized by a wh-expression to the left edge and a subordinator to the right edge. Section 4.2 discusses the second type of headless relative clause: both the subtype known as a light-headed relative clause and the subtype that lacks both a light head and a wh-expression, in which a case marker or the topic marker is found to its right edge. 


\subsection{Free relative clauses}

Free relative clauses are headless relatives that are introduced by a $w h$-expression. A subordinator appears at the right edge of the predicate, as in the embedded interrogative clause (Section 2). Free relative clauses occur before matrix clauses, while embedded interrogative clauses follow their matrix clause. All three kinds of subordinators are used. Maximal, existential and free choice FRs are distinguished from each other by the type of wh-expression used: in maximal FRs (Section 4.1.1) only the two locative $w h$-words may be used, in existential FRs (Section 4.1.2) different $w h$ words are used, and in free choice FRs (Section 4.1.3) the $w h$-word is reduplicated.

\subsubsection{Maximal free relative clauses}

Maximal free relative clauses (Max-FRs) are limited in Pesh; there are very few examples in the corpus. The majority of headless relative clauses with a maximal interpretation are constructed without a $w h$-expression, as we discuss in Section 4.2.2. Only the locative $w h$-expressions piah 'where' (38) and pikan 'where, in which direction' (39) can occur, as in headed relative clauses with a wh-expression (Section 3). The subordinator may be any of the three subordinators discussed in Section 1.5: the uncertainty marker $=\operatorname{sri}(38)$, the dubitative $=k a n$ (39) or the certainty marker $=m a(40)$.

(38) pyắh nằísrí pàyó nằíftàkíwá

$\begin{array}{lll}\text { [pi-ah nã-u-i=sri] } & \text { pa=yo } & \text { nã-i } \int \text {-ta-ka-i-wa } \\ \text { place-NMLZ go-SBJ2-PRS=UNCRT } & \text { PRO2=COM/INS } & \text { go-DES-OBJ1-make-SBJ3SG-PRS }\end{array}$

'I want to go with you where you should go.'

(39) pìkế pāyj̀kế fẾnî́nấ
[pi=ken $\quad \emptyset$-pa-k- $\emptyset$-i=ken]
$\emptyset-\int a \mathrm{a}-\emptyset-\mathrm{tV}-\mathrm{i}=\mathrm{na}$
place=SIM OBJ3SG-take-K-SBJ3SG-PST=DBT
OBJ3SG-See-SBJ3SG-NEG-PST=REP

'They said that he didn't see where she could have taken him.' $\{\mathrm{txt}\}$

(40) pyấn tfórímà tfằbrí
[pi-ah t ta-u-ri=ma]
$\emptyset$-t $\widetilde{a}$-ber-i
place-NMLZ be_there-SBJ2-PST=CRT OBJ3SG-See-SBJ1PL-PST
'We saw where you were born.' $\quad\{$ txt $\}$

The structures in (38-40) are attested in the corpus for maximal free relative clauses, but the most frequent strategy for the locative role is the one illustrated in (41), which lacks a $w h$-expression. We discuss it in Section 4.2.2.

(41) tJóríyấ tjằbrí
[t $\mathrm{a}-\mathrm{u}-\mathrm{ri}=\mathbf{y} \tilde{a}]$
$\emptyset$-t $\tilde{a}$-ber-i
be_there-SBJ2-PST=LOC OBJ3SG-See-SBJ1PL.EXCL-PST
'We saw where you were born.' $\quad\{\mathrm{txt}\}$ 
Example (42a) was found in a text and shows the construction of a headless relative clause that lacks a wh-expression that receives a maximal interpretation. My informants reject the corresponding sentence containing the Max-FR in (42b).

(42) a. tùhúrímà à̀álí

$\begin{array}{ll}\text { [Ø-tuh-u-ri=ma }] & \emptyset \text {-ã?-a- } \int \mathrm{i} \\ \text { OBJ3SG-cook-SBJ2-PST=TOP } & \text { OBJ3SG-eat-SBJ1SG-PST.REC } \\ \text { 'I ate what you cooked.' }\{\text { txt }\} & \end{array}$

b. *ĩrá tùhúrísrí à̀?áji

$\begin{array}{lll}{[\tilde{\mathbf{I}}=\mathbf{r a}} & \emptyset \text {-tuh-u-ri=sri }] & \emptyset \text {-ã?-a- } \int \mathrm{i} \\ \text { DEM.PROX=ABS } & \text { OBJ3SG-cook-SBJ2-PST=UNCRT } & \text { OBJ3SG-eat-SBJ1SG-PST.REC } \\ \text { Intended reading: 'I ate what you cooked.' } & \end{array}$

\subsubsection{Existential free relative clauses}

In this section, I discuss existential free relative clauses (Ex-FRs). The corpus contains several examples of Ex-FRs. As in all other languages with Ex-FRs, they occur as the complement of a matrix predicate conveying the meaning of existence. The predicate $t \int a$ 'be there, inhabit, exist, have' is the most often used for Ex-FRs, as shown in (43) and (44).

WHO / Subject in the FR

(43) ãyấh mã̀ táyá énèyè písrí tfúà

\begin{tabular}{|c|c|c|}
\hline$\tilde{a}=y \tilde{a}=m a$ & {$[\mathbf{t a}=\mathbf{y a} \quad$ ena } & $\emptyset$-eye $\int-\emptyset$-pi=sri $]$ \\
\hline $\begin{array}{l}\text { DEM.DIST=LOC=TOP } \\
\text { tfa- } \emptyset \text {-wa } \\
\text { be_there-SBJ3SG-PRS }\end{array}$ & DEM.DIST=ERG good & OBJ3SG-sing-SBJ3SG-FUT=UNCRT \\
\hline
\end{tabular}

WHAT / Instrument in the FR

(44) í̀yó kàkòrspésrí tàkàtjítwa

$[\tilde{\mathbf{l}}=\mathbf{y o} \quad \emptyset$-ka-kors- $\varnothing$-pi=sri]

DEM.PROX=COM/INS OBJ3SG-APPL-write-SBJ3SG-FUT=UNCRT

ta-ka-t $\int a-i-t V-w a$

OBJ1-APPL.R-be_there-SBJ3SG-NEG-PRS

'I don't have anything to write with.'

In Ex-FRs, wh-expressions occur in clause initial position, as in all other $w h$-clauses in Pesh we have seen so far. For discourse reasons, an adverb, such as ĩyama 'here', can appear before the whexpression (45). The verb of the Ex-FR is in clause-final position. In Ex-FRs, the verb is marked by one of the three subordinators (Section 1.5), the uncertainty marker $=s r i$ (44), the certainty marker $=m a(45)$, or the dubitative $=k a n(51)$. 
WHICH / Subject in the FR

(45) yấn mã̀ pìyàrà té?ũntãt fếmímà t fítwà

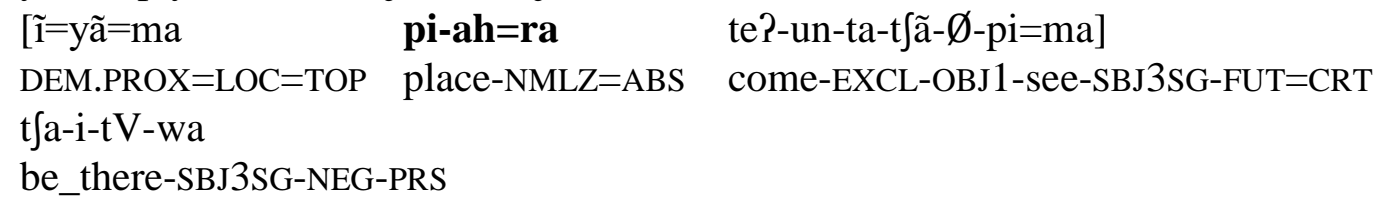

'There is no one who will come here to see us.' $\{t x t\}$ (Lit. 'There isn't who will come here to see us.')

The verb of Ex-FRs always appears marked by a future tense that expresses the possibility that the event will happen or has happened, even if the expressed event seems to be real and current, as in (46) where the subordinator is the certainty marker =ma occurring together with the future marker -pi. My consultants reject any other tense marking, like the present marker -wa in (47). Ex-FRs carry the future marker even if the matrix clause is marked as past triggering a counterfactual interpretation of unrealized possibility, as in as in (48).

WHERE / Locative in the FR

(46) pyắh tfópímà pìkàt Júà

[pi-ah t ta-u-pi=ma] pi-ka-t $\int a-\emptyset-w a$

place-NMLZ be_there-SBJ2-FUT=CRT OBJ2-APPL.R-be_there-SBJ3SG-PRS

'You have a place where you live.' $\quad\{\mathrm{txt}\}$

(47) *pyấh t fówámà pìkàtfúà

pi-ah t ta-u-wa=ma pi-ka-t $\int a-\emptyset$-wa

place-NMLZ be_there-SBJ2-PRS=CRT OBJ2-APPL.R-be_there-SBJ3SG-PRS

Intended reading: 'You have a place where you live.'

(48) pyấh nằpárísrí tàkàtfíí

$\begin{array}{lll}\text { [pi-ah } & \text { nã-pa-ri=sri] } & \text { ta-ka-t } \int \mathrm{a}-\mathrm{i}-\mathrm{i} \\ \text { place-NMLZ } & \text { go-SBJ1SG.FUT-PST=UNCRT } & \text { OBJ1-APPL.R-be_there-SBJ3SG-PST } \\ \text { 'I had a place where I could have gone.' } & \end{array}$

Other verbs are attested, such as proh 'look for' (54) and pãs 'find' $(49,50)$.

Sixteen of the seventeen $w h$-expressions are used in Ex-FRs. In addition to the four $w h$-expressions that occur in examples (44-47), the other twelve are given in (48-59):

WHO / Object in the FR

(49) tárá èyè písrí pắskútJí

$\begin{array}{lll}{[\mathbf{t a}=\mathbf{r a}} & \left.\varnothing \text {-eye } \int-\varnothing \text {-pi=sri }\right] & \emptyset \text {-pãs-k-u-t } \int \mathrm{i} \\ \text { DEM.DIST=ABS } & \text { OBJ3SG-sing-SBJ3SG-FUT=UNCRT } & \text { OBJ3SG-find-K-SBJ3SG-PST.REC } \\ \text { 'He found someone to sing for.' } & \end{array}$


WHO / Comitative in the FR

(50) táyó kàtũ̀)pésrí pã́skí

[ta=yo katũf- $\varnothing$-pi=sri $] \quad \emptyset$-pãs-k- $\varnothing-\mathrm{i}$

DEM.DIST=COM/INS work-SBJ3SG-FUT=UNCRT OBJ3SG-find-K-SBJ3SG-PST

'He found somebody to work with.' $\{$ txt $\}$

WHO / Locative in the FR

(51) táyã́ nã̀pákánwã́ tàkàtJítwa

[ta=yã nã-pa=kan=wã $] \quad$ ta-ka-t $\int a-i-t-w a$

DEM.DIST=LOC go-SUBJ1SG.FUT=DBT=PSB OBJ1-APPL-be_there-SBJ3SG-NEG-PRS

'I don't have anyone's house to go to.' $\{$ txt $\}$

WHO / Genitive in the FR

(52) táPà àkà?órá séhpísrí pắskárí

[ta-Peh a-kaPo=ra $\quad$-seh- $\varnothing$-pi-i=sri]

DEM.DIST-FT.POSS.PRO POSS3SG-house=ABS OBJ3SG-burn-SBJ3SG-FUT-PST=UNCRT

$\emptyset$-pãs-k-a-ri

OBJ3SG-find-K-SBJ1SG-PST

'I found anybody whose house they said was burnt.'

WHAT / Subject in the FR

(53) ĩ́yá àhírpísrí tjùá

[ĩ=ya a-hir-i-pi=sri]

DEM.PROX=ERG OBJ3SG-know-SBJ3SG-FUT=UNCRT

t $\int \mathrm{a}-\emptyset$-wa

be_there-SBJ3SG-PRS

'There is something he would like to know.' $\quad\{t x t\}$

-WHAT / Object in the FR

(54) ĩ́rá pã̀yhpásrí próhàwà

[ĩ=ra pi-ãyh-pa=sri] $\quad \emptyset$-proh-a-wa

DEM.PROX=ABS OBJ2-give.OBJ1/2-SBJ1SG.FUT=UNCRT OBJ3SG-look_for-SBJ1SG-PRS

'I'm looking for something I should give you' $\{\mathrm{txt}\}$

HOW / Manner in the FR

(55) ĩkàn pàbèrpékén ừntãkàtfùá

[ĩ=kan $\quad \emptyset$-pa-ber-pe=ken]

DEM.PROX=SIM OBJ3SG-take-SBJ1PL.EXCL-FUT=DBT

ũn-ta-ka-t $\int a-\emptyset$-wa

EXCL-OBJ1-APPL.R-be_there-SBJ3SG-PRS

'We may have a way to take it.' $\{$ txt $\}$ 
WHEN / Temporal in the FR

(56) íkàwàr tè?párísrí próhàrí

[ĩ=kawar te?-pa-ri=sri] $\quad \emptyset$-proh-a-ri

DEM.PROX=? come-SBJ1SG.FUT-PST=UNCRT OBJ3SG-look_for-SBJ1SG-PST

'I looked for him at a time when I was supposed to come.'

WHEN / Temporal in the FR

(57) ã́hĩ̀ nã̀pámà pã́skàrí

[ã =hĩ nã-pa=ma $\quad \emptyset$-pãs-k-a-ri

DEM.DIST=? go-SBJ1SG.FUT=CRT OBJ3SG-find-K-SBJ1SG-PST

'I found a moment in which I was able to go (somewhere).' $\{\mathrm{txt}\}$

WHEN / Temporal in the FR

(58) ãpérí tè?pámà kè tàkàt ftùá

\begin{tabular}{|c|c|}
\hline$[\tilde{a}-\mathbf{p e}=\mathbf{r i}$ & te?-pa=ma] \\
\hline $\begin{array}{l}\text { DEM.DIST-times=TEMP/MAN } \\
\text { ta-ka-t } \int a-i-t V-\text { wa }\end{array}$ & come-SBJ1SG.FUT=CRT \\
\hline $\begin{array}{l}\text { BJ1-APPL.R-be_there-SBJ3S } \\
\text { I haven't decided on a time }\end{array}$ & $\begin{array}{l}\text {-NEG-PRS } \\
\text { at which I will come' }\{\end{array}$ \\
\hline
\end{tabular}

WHERE / Locative in the FR

(59) píkán ò̀:npárísrí tàkàtJíi

[pi=kan õ:-n-pa-ri=sri] ta-ka-t $\int a-i-i$

place-NMLZ sleep-DUR-SBJ1SG.FUT-PST=CRT OBJ1-APPL.R-be_there-SBJ3SG-PST

'I had a place where I could have slept.' $\{\mathrm{txt}\}$

HOW MANY_HOW MUCH / Subject (quantity) in the FR

(60) pí tè?kèrpírímà pã́skàrí

$\begin{array}{lll}\text { [pi } & \text { te?-k-er-pi-ri=ma }] & \emptyset \text {-pãs-k-a-ri } \\ \text { how_many/much } & \text { come-K-SBJ3PL-FUT-PST=CRT } & \text { OBJ3SG-find-K-SBJ1SG-PST } \\ \text { 'I found several (people) who would have come.' } & \{t x t\}\end{array}$

In Ex-FRs, the enclitic case of the wh-word always marks the role of the $w h$-word in the FR. Of the seventeen $w h$-words, sixteen are used in Ex-FRs (Table 5). 
Table 5. Distribution of $w h$-expression in Ex-FRs

\begin{tabular}{|c|c|c|c|}
\hline $\begin{array}{l}\text { Basic } \\
\text { meaning }\end{array}$ & Further specifications & Pesh wh- & Distribution \\
\hline \multirow[t]{5}{*}{ WHO } & 'who' $+V_{\text {tr }}$ & $t a=y a$ & $\sqrt{ }$ \\
\hline & $\begin{array}{l}\text { 'who' }+V_{\text {intr }} \\
\text { 'to who' }+V_{\text {tr }}\end{array}$ & $t a=r a$ & $\sqrt{ }$ \\
\hline & 'with who' & $t a=y o$ & $\sqrt{ }$ \\
\hline & 'in whose house' & $t a=y \tilde{a}$ & $\sqrt{ }$ \\
\hline & 'whose'+ N & ta-?eh & $\sqrt{ }$ \\
\hline \multirow[t]{3}{*}{ WHAT } & 'what' $+V_{\text {tr }}$ & $\tilde{l}=y a$ & $\sqrt{ }$ \\
\hline & $\begin{array}{l}\text { 'what' }+V_{\text {intr }} \\
\text { 'to what' }+V_{\text {tr }}\end{array}$ & $\tilde{l}=r a$ & $\sqrt{ }$ \\
\hline & 'with what' & $\tilde{l}=y o$ & $\sqrt{ }$ \\
\hline \multirow[t]{2}{*}{ WHERE } & & $p i-a h$ & $\sqrt{ }$ \\
\hline & & $p i=k a n$ & $\sqrt{ }$ \\
\hline \multirow[t]{3}{*}{ WHEN } & 'when' (past) & $\tilde{l}=k a w a r$ & $\sqrt{ }$ \\
\hline & 'when' (present/future) & $\tilde{a}=h \tilde{\imath}$ & $\sqrt{ }$ \\
\hline & 'at what time' & $\tilde{a}-p e=r i$ & $\sqrt{ }$ \\
\hline HOW & & $\tilde{\imath}=\operatorname{kan}(-k a)$ & $\sqrt{ }$ \\
\hline WHY & & $\tilde{l}=r e \int$ & $*$ \\
\hline WHAT/WHICH & & $p i-a h=r a$ & $\sqrt{ }$ \\
\hline $\begin{array}{l}\text { HOW MUCH/ } \\
\text { HOW MANY }\end{array}$ & & pif & $\sqrt{ }$ \\
\hline
\end{tabular}

Note. $\sqrt{ }$ : acceptable; * not acceptable.

The construction with $\tilde{\imath}=$ ref 'why' is the only one that is impossible. In this context the subordinator for reason $=r e \int$ is used (61a) and the use of the $w h$-word is ungrammatical (60b).

(61) a. árwấ òníh tàkàkìó àrkàpáftè?nềríré t tjirí

[arwã onih ta-kaki=yo a-r-kapaf-te?-nã-er-ri=ref]

man dead POSS1-mother=COM/INS OBJ3SG-APPL.P-speak-come-go-SBJ3PL-PST=REAS tja-i-ri

be_there-SBJ3SG-PST

'There is some reason why the dead men came to speak with my mother and went away.' $\{\mathrm{txt}\}$

b. *î́ré wé? kàtû̀jpísrí pắskàrí
$*\left[\tilde{i}=\mathbf{r e} \int\right.$
we? katũf- $\emptyset$-pi=sri]
Ø-pãs-k-a-ri
* DEM.PROX=REAS a_lot work-SBJ3SG-FUT=UNCRT
OBJ3SG-find-K-SBJ1SG-PST
Intended reading: 'I found a reason why he could work hard.'

When piah 'where' and pikan 'where, in which direction' are used, it is easy to distinguish between Ex-FRs and Max-FRs (Section 4.1.1): first, the tense of the verb is always the future in Ex-FRs; and second, the verb of the matrix clause in Ex-FRs is an existential predicate. 


\subsubsection{Free choice free relative clauses}

Free choice free relative clauses (FC-FRs) are easily distinguishable from the two preceding FRs, because the $w h$-expression is reduplicated. In Pesh, verbs and nouns may be reduplicated with an iterative meaning and with adjectives to mark intensity. For FC-FRs, there are two possibilities: either only the $w h$-expression is reduplicated (62), or the coordinator $=r i$ and the indefinite marker $=n a($ Section 1.4) are added to each element (63).

WHO / Subject in the FR

(62) táré tárá tókkî Jkúkán nàspé

[ta=ra ta=ra tok-k-if- $\varnothing$-ka-i-wa=kan]
DEM.DIST=ABS DEM.DIST=ABS enter-K-DES-OBJ3SG-make-SBJ3SG-PRS=DBT
nas- $\varnothing$-pi
jump.AFF-SBJ3SG-FUT
'Whoever would like to enter will jump.' $\quad\{$ txt $\}$

WHO / Comitative in the FR

(63) tàyórínà tàyórínà tè?písrí wípá

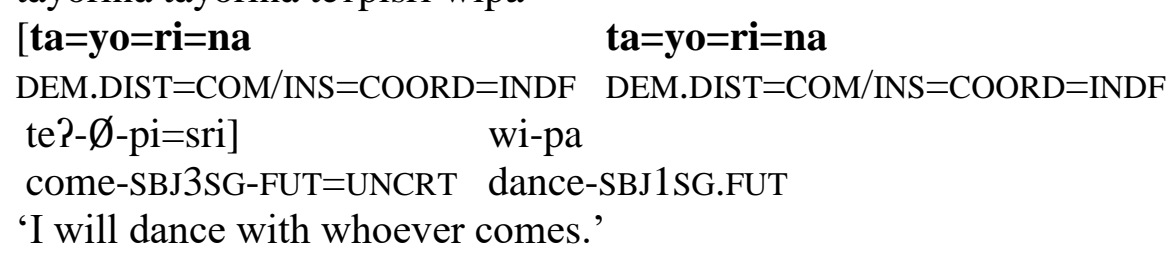

Usually, the verb of the FC-FR is in the future tense. It can appear in another tense, and when this happens, the verb of the matrix clause must be in future tense. The predicate may end with the uncertainty marker $=s r i(63)$, the dubitative $=k a n(62)$ or the certainty marker $=m a(67)$. The readings is generally that of indifference to available choices, but ignorance is also a possible reading $(62)$.

In FC-FRs, the enclitic case of the $w h$-word always marks the role of the FR in the matrix clause. See examples (63), (69) and (73) where the two roles are different.

Fourteen of the seventeen $w h$-expressions are used in FC-FRs. In addition to the two wh-words that occur in examples (62) and (63), the other twelve are given in (64-74):

wHO / Subject in the FR

(64) táyá táyá kàkòrspésrí kàkòrspí

\begin{tabular}{|c|c|c|}
\hline$[\mathbf{t a}=\mathbf{y a}$ & ta $=\mathbf{y a}$ & $\emptyset$-ka-kors- $\varnothing$-pi=sri] \\
\hline DEM.DIST=ERG & DEM.DIST=ERG & OBJ3SG-APPL-write-SBJ3SG-FUT=UNCRT \\
\hline$\emptyset$-ka-kors- Ø-pi & & \\
\hline $\begin{array}{l}\text { OBJ3SG-APPL-W' } \\
\text { 'Whoever can }\end{array}$ & $\begin{array}{l}\text {-SBJ3SG-FUT } \\
\text { e may do so. }\end{array}$ & $x t\}$ \\
\hline
\end{tabular}


WHO / Locative in the FR

(65) táyắrínà táyắrínà énpítífpísrí nằúh

$[\mathbf{t a}=\mathbf{y a ̃}=\mathbf{r i = n a} \quad \mathbf{t a}=\mathbf{y a}=\mathbf{r i}=\mathbf{n a}$

DEM.DIST $=$ LOC $=$ COORD $=$ INDF DEM.DIST $=$ LOC $=$ COORD $=I N D F$ good

pi-tif- $\varnothing$-pi=sri] nã-u-h

OBJ2-become-SBJ3SG-FUT=UNCRT go-SBJ2SG-IMP

'Go to whichever house you'd like.'

WHO / Genitive in the FR

(66) tá?àrínà tá?àrínà àkákì ờ:nípírísrí ừnàhárí

[ta-Peh=ri=na

DEM.DIST-FT.POSS.PRO $=\mathrm{COORD}=\mathrm{INDF}$

a-kaki

õ-n-i-pi-ri=sri]

\section{ta-Peh=ri=na}

DEM.DIST-FT.POSS.PRO $=\mathrm{COORD}=\mathrm{INDF}$

POSS3SG-mother sleep-DUR-SBJ3SG-FUT-PST=UNCRT CAUS-Say-SBJ1SG-PST

'I greeted whoever's mother is supposed to be dead.' $\{$ txt $\}$

WHAT / Subject in the FR

(67) $\tilde{1}=y a ́$ î́=yá bõnpémà énàtífpí

[ĩ=ya $\quad \tilde{\mathbf{i}}=\mathbf{y a} \quad$ bõ-n- $\emptyset$-pi=ma]

DEM.DIST $=$ ERG DEM.DIST $=$ ERG bloom-DUR-SBJ3SG-FUT $=$ CRT

ena $\emptyset$-tif- $\emptyset$-pi

good OBJ3SG-become-SBJ3SG-FUT

'No matter what blooms, it will be beautiful' $\{\mathrm{txt}\}$

WHAT / Object in the FR

(68) ĩ́rî́rí tàkàtùhúmà ấpấhã́?

$\begin{array}{lll}{[\tilde{\mathbf{i}}=\mathbf{r a}} & \tilde{\mathbf{i}}=\mathbf{r a} & \text { ta-ka-tuh-u-wa=ma }] \\ \text { DEM.PROX=ABS } & \text { DEM.PROX=ABS } & \text { OBJ1-APPL.R-cook-SBJ2-PRS=CRT }\end{array}$

$\emptyset$-ã-pa=hã?

OBJ3SG-eat-SBJ1sG.FUT=FOC

'I will eat whatever you cook for me.'

WHAT / Instrumental in the FR

(69) ĩ́yó î́yó tã̀yhúpékán kàtũ̀ pá

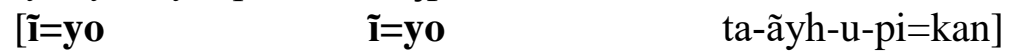

DEM.PROX $=\mathrm{COM} / \mathrm{INS}$ DEM.PROX $=\mathrm{COM} / \mathrm{INS}$ OBJ 1 -give.OBJ1/2-SBJ2-FUT=DBT

katũf-pa

work-SBJ1SG.FUT

'I will work with whatever (instrument) you might give me.' 
WHEN / Temporal in the FR

(70) ấpérírnà ấpérírnà nồpísrí nằpá

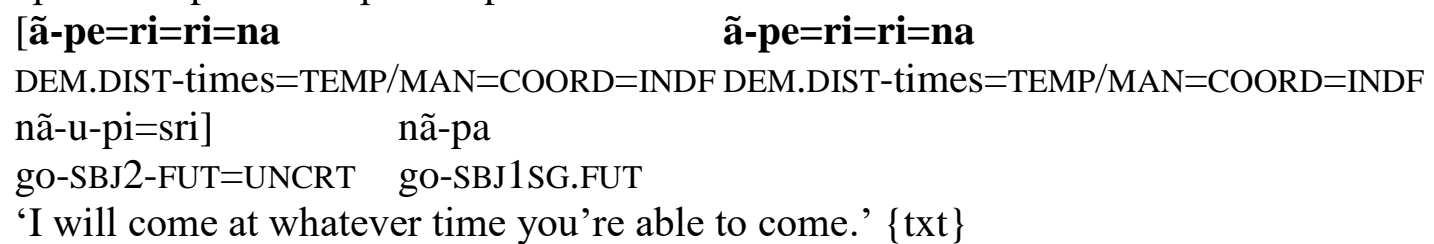

WHERE / Locative in the FR

(71) pjáh pjā tèjpāmò pr ònáwá:
[pi-ah
pi-ah
te $\int$-pa $=$ ma]
$\emptyset$-proh-a-wa
place-NMLZ place-NMLZ travel-SBJ1SG.FUT=CRT OBJ3SG-look_for-SBJ1SG-PRS

'I am looking for anywhere to travel to.' $\{t x t\}$

WHERE / Locative in the FR

(72) píkánrínà píkánrínà ã?párísrí òhárí

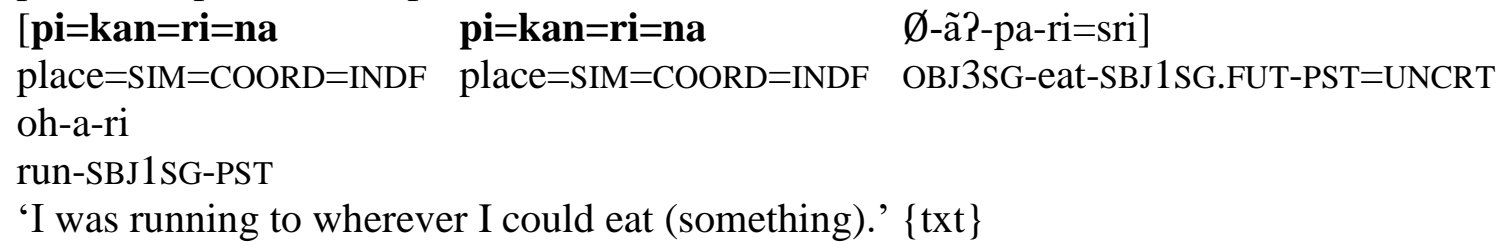

WHICH / Object in the FR

(73) pìhàrà pĩ̀yằrà próhnã̀ùmà àrkàpàhã́?

$\begin{array}{lll}\text { [pi-ah=ra } & \mathbf{p i}-\mathbf{a h}=\mathbf{r a} & \emptyset \text {-proh-nã-u-wa=ma }] \\ \text { place=NMLZ=ABS } & \text { place=NMLZ=ABS } & \text { OBJ3SG-look_for-go-SBJ2-PRS=CRT } \\ \text { a-r-ka-pa=hã? } & & \\ \text { OBJ3SG-APPL.P-make-SBJ1SG.FUT=FOC }\end{array}$

'I will hit whichever thing you go looking for.' $\{\mathrm{txt}\}$

HOW MANY_HOW MUCH / Subject (quantity) in the FR

(74) pifrínà pifrínà nèpísrí doña Juana Carolina pàtàóhrjè̀hwá

$\left[\right.$ pi $\int=$ ri=na $\quad$ pi $\int=r i=n a$

how_many/much=COORD=INDF how_many/much=COORD=INDF

nã-i-pi=sri] doña Juana Carolina pa-ta-ohria $\quad \emptyset$-yẽh- $\emptyset$-wa

go-SBJ3SG-FUT=UNCRT doña Juana Carolina INCL-POSS1-culture OBJ3SG-Say-SBJ3SG-PRS

'Doña Juana Carolina talks about our culture to anyone who can come.' $\{$ txt $\}$

Of the seventeen wh-expressions, fourteen can function in free choice free relatives (Table 6). 
Table 6. Distribution of $w h$-expression in FC-FRs

\begin{tabular}{|c|c|c|c|}
\hline $\begin{array}{l}\text { Basic } \\
\text { meaning }\end{array}$ & Further specifications & Pesh $w h$ - & Distribution \\
\hline \multirow[t]{5}{*}{ WHO } & 'who' $+V_{\text {tr }}$ & $t a=y a$ & $\sqrt{ }$ \\
\hline & $\begin{array}{l}\text { 'who' }+V_{\text {intr }} \\
\text { 'to who' }+V_{\text {tr }}\end{array}$ & $t a=r a$ & $\sqrt{ }$ \\
\hline & 'with who' & $t a=y o$ & $\sqrt{ }$ \\
\hline & 'in whose house' & $t a=y \tilde{a}$ & $\sqrt{ }$ \\
\hline & 'whose'+N & ta-Peh & $\sqrt{ }$ \\
\hline \multirow[t]{3}{*}{ WHAT } & 'what' $+V_{\text {tr }}$ & $\tilde{l}=y a$ & $\sqrt{ }$ \\
\hline & $\begin{array}{l}\text { 'what' }+V_{\text {intr }} \\
\text { 'to what' }+V_{\text {tr }}\end{array}$ & $\tilde{\imath}=r a$ & $\sqrt{ }$ \\
\hline & 'with what' & $\tilde{l}=y o$ & $\sqrt{ }$ \\
\hline \multirow[t]{2}{*}{ WHERE } & & $p i-a h$ & $\sqrt{ }$ \\
\hline & & pi=kan & $\sqrt{ }$ \\
\hline \multirow[t]{3}{*}{ WHEN } & ‘when' (past) & $\tilde{l}=k a w a r$ & $*$ \\
\hline & 'when' (present/future) & $\tilde{a}=h \tilde{\imath}$ & $*$ \\
\hline & 'at what time' & $\tilde{a}-p e=r i$ & $\sqrt{ }$ \\
\hline HOW & & $\tilde{\imath}=\operatorname{kan}(-k a)$ & $\mathrm{n} / \mathrm{a}$ \\
\hline WHY & & $\tilde{l}=r e \int$ & $*$ \\
\hline WHAT/WHICH & & $p i-a h=r a$ & $\sqrt{ }$ \\
\hline $\begin{array}{l}\text { HOW MUCH/ } \\
\text { HOW MANY }\end{array}$ & & pif & $\sqrt{ }$ \\
\hline
\end{tabular}

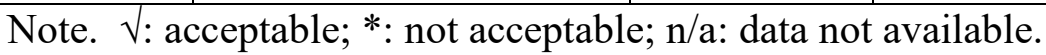

As with Ex-FRs, the construction for $\tilde{i}=r e$ / 'why' is not possible in FC-FRs, since a subordinate clause is used in this context (75a) with the subordinator $=$ ras $\left(\right.$ a dialectal variation of $=r e \int$ used in the Culmi dialect). The construction in (75b) is ungrammatical; according to my informants the only possibility is the construction in (75a).

(75) a. kàtù̀jkáwá éntátífkùrás

katũf-k-a-wa [ena ta-tif-k- $\emptyset$-wa=ras]

work-K-SBJ1SG-PRS good OBJ1-become-K-SBJ3SG-PRS=REAS

'I work because I like it.' $\{t x t\}$

b. *î́ré î́rés éntátífkwásrí kàtừjpá

[ĩ=re $\quad \tilde{\mathbf{l}}=\mathbf{r e} \int \quad$ ena ta-tif-k- $\emptyset$-wa $=$ sri]

DEM.PROX=REAS DEM.PROX=REAS good OBJ1-become-K-SBJ3SG-PRS=UNCRT

katũf-pa

work-SBJ1SG.FUT

Intended reading: 'I work whether I like it or not.' 
Contrary to Ex-FRs, in FC-FRs the constructions for 'when', that is, $\tilde{l}=$ kawar for a past event (76), and $\tilde{a}=h \tilde{\imath}$ for a present or future event (77), are ungrammatical. My informants always propose constructions with the temporal subordinator $=m \tilde{a}(78)$.

*î́kàwàr î́kàwàr paulina wàpírísrí kètfá tè?párí

[ĩ=kawar $\tilde{\mathbf{i}=k a w a r} \quad$ Paulina wa- $\emptyset$-pi-ri=sri] DEM.PROX=? DEM.PROX=? Paulina wake_up-SBJ3SG-FUT-PST=UNCRT yesterday te?-pa-ri come-SBJ1SG.FUT-PST

Intended reading: 'Yesterday, I would have come whenever Paulina woke up.'

(77) *ấhî́ ấhĩ́ tè?pímà nàpá

$\begin{array}{llll}{[\tilde{\mathbf{a}}=\mathbf{h i}} & \tilde{\mathbf{a}}=\mathbf{h} \tilde{\mathbf{i}} & \text { te} \mathbf{P}-\emptyset \text {-pi=ma }] & \text { na-pa } \\ \text { DEM.DIST=? } & \text { DEM.DIST=? } & \text { come-SBJ3SG-FUT=CRT } & \text { go-SBJ1SG.FUT }\end{array}$

Intended reading: 'I will go whenever he comes.'

(78) nàpá tè?pímã̀

na-pa [te?-Ø-pi=mã]

go-SBJ1SG.FUT come-SBJ3SG-FUT=when/if

'I will go when he comes.'

Conversely, in FC-FRs, the temporal $w h$-expression that indicates a precise moment $\tilde{a}=p e=r i$ 'at what time' is used (70).

\subsubsection{Summary}

The free relatives that use a $w h$-expression to the left edge and a subordinator to the right edge, are used for maximal, existential, and free choice free relative clauses. Each of the constructions is distinguishable by features of the $w h$-expression and/or by certain restrictions regarding the tense of the verb in the free relative clause or the type of verb in the matrix clause. In Max-FRs, only the locative wh-words piah 'where' and pikan 'where, in which direction' can appear, as in the case of headed relative clauses with wh-expressions. In Ex-FRs different $w h$-words can be used, but there is a restriction, since only the future tense is used for the verb in free FRs. In FC-FRs, the $w h$-word is obligatorily reduplicated.

Table 7 shows four different distributions of wh-expressions: first, the two locative $w h$-words, which are the most widespread, appear in all types of clauses; second, the wh-expressions for 'which', 'who', 'what' and 'how many, how much' appear in Ex-FRs and FC-FRs; third, two whexpressions for tense, $\tilde{l}=k a w a r$ and $\tilde{a}=h \tilde{\imath}$ 'when' show a different behavior according to the type of FR in which they appear: they can never appear with headed RCs and Max-FRs, and on the contrary are used with Ex-FRs (interestingly only the more precise $w h$-word $\tilde{a}$-pe $=r i$ 'at what time' can be used in FC-FRs) and fourth, the $w h$-word $\tilde{l}=r e \int$ ' why' is not used in relative clauses. Data are not available for the $w h$-expression $\tilde{l}=k a n$ 'how' in FC-FRs. 
Table 7. Distribution of $w h$-expression across constructions

\begin{tabular}{|c|c|c|c|c|c|c|}
\hline $\begin{array}{l}\text { Basic } \\
\text { meaning }\end{array}$ & Further specifications & Pesh wh- & HRC & Max-FR & Ex-FR & FC-FR \\
\hline \multirow[t]{5}{*}{ WHO } & 'who' $+V_{\text {tr }}$ & $t a=y a$ & $*$ & $*$ & $\sqrt{ }$ & $\sqrt{ }$ \\
\hline & $\begin{array}{l}\text { 'who' }+V_{\text {intr }} \\
\text { 'to who' }+V_{\text {tr }}\end{array}$ & $t a=r a$ & $*$ & $*$ & $\sqrt{ }$ & $\sqrt{ }$ \\
\hline & 'with who' & $t a=y o$ & $*$ & $*$ & $\sqrt{ }$ & $\sqrt{ }$ \\
\hline & 'in whose house' & $t a=y \tilde{a}$ & $*$ & $*$ & $\sqrt{ }$ & $\sqrt{ }$ \\
\hline & 'whose'+ N & ta-?eh & $*$ & $*$ & $\sqrt{ }$ & $\sqrt{ }$ \\
\hline \multirow[t]{3}{*}{ WHAT } & 'what' $+V_{\text {tr }}$ & $\tilde{l}=y a$ & $*$ & $*$ & $\sqrt{ }$ & $\sqrt{ }$ \\
\hline & $\begin{array}{l}\text { 'what' }+V_{\text {intr }} \\
\text { 'to what' }+V_{\text {tr }}\end{array}$ & $\tilde{\imath}=r a$ & $*$ & $*$ & $\sqrt{ }$ & $\sqrt{ }$ \\
\hline & 'with what' & $\tilde{l}=y o$ & $*$ & $*$ & $\sqrt{ }$ & $\sqrt{ }$ \\
\hline \multirow[t]{2}{*}{ WHERE } & & $p i-a h$ & $\sqrt{ }$ & $\sqrt{ }$ & $\sqrt{ }$ & $\sqrt{ }$ \\
\hline & & $p i=k a n$ & $\sqrt{ }$ & $\sqrt{ }$ & $\sqrt{ }$ & $\sqrt{ }$ \\
\hline \multirow[t]{3}{*}{ WHEN } & 'when' (past) & $\tilde{l}=k a w a r$ & $*$ & $*$ & $\sqrt{ }$ & $*$ \\
\hline & 'when' (present/future) & $\tilde{a}=h \tilde{\imath}$ & $*$ & $*$ & $\sqrt{ }$ & $*$ \\
\hline & 'at what time' & $\tilde{a}-p e=r i$ & $*$ & $*$ & $\sqrt{ }$ & $\sqrt{ }$ \\
\hline HOW & & $\tilde{l}=k a n(-k a)$ & $*$ & $*$ & $\sqrt{ }$ & $\mathrm{n} / \mathrm{a}$ \\
\hline WHY & & $\tilde{l}=r e \int$ & $*$ & $*$ & $*$ & $*$ \\
\hline WHAT/WHICH & & $p i-a h=r a$ & $*$ & $*$ & $\sqrt{ }$ & $\sqrt{ }$ \\
\hline $\begin{array}{l}\text { HOW MUCH/ } \\
\text { HOW MANY }\end{array}$ & & pif & $*$ & $*$ & $\sqrt{ }$ & $\sqrt{ }$ \\
\hline
\end{tabular}

Note. $\sqrt{ }$ : acceptable; *: not acceptable; n/a: data not available.

Ex-FRs and FC-FRs show a relevant difference according to the role of the wh-expression: in ExFRs, the enclitic case of the $w h$-expression marks the role of the $w h$-expression in the FR whereas in FC-FRs, the enclitic case of the wh-expression marks the role of the FR in the matrix clause.

\subsection{Headless relative clauses that lack a $w h$-expression}

In headless relative clauses that lack a wh-expression, a case marker or else the topic marker is found to the right edge of the $\mathrm{RC}$, as in headed relative clauses that lack $w h$-expressions (see Section 3). Two types will be described: first, light-headed relative clauses (Section 4.2.1), and second, headless relatives without a light-head or a wh-expression (Section 4.2.2).

\subsubsection{Light-headed relative clauses}

Light-headed relative clauses (LHRs) behave like headed relative clauses that lack $w h$-expressions (Section 3). The enclitic that occurs at the end of a LHR may be a case marker or a topic marker. When the light-head is a genitive or an argument in the LHR, the enclitic corresponds to the syntactic role of the light-head in the matrix clause, as comitative/instrumental in (79). 
Medial demonstrative to?

Subject in the LHR - Instrumental in the MC

(79) tó? tàkàtJùwáyó kàtũ̀fkáwá

$\begin{array}{lll}\text { [to? } & \left.\text { ta-ka-t } \int a-i-w a\right]=y o & \text { katũ } \int-k-a-w a \\ \text { DEM.MED } & \text { OBJ1-APPL.R-be_there-SBJ3SG-PRS=COM/INS } & \text { work-K-SBJ1SG-PRS }\end{array}$

'I work with the one I have always worked with.' $\quad\{t x t\}$

If the light head functions as the genitive and the subject in the LHR, the marker $=m a$ is used (80, 81). In this context, this marker does not indicate topic as no opposition with focus is possible. The alignment in light-headed relatives is subject-accusative (see Section 3 for headed relative clauses and Chamoreau forthcoming.b). The marker $=m a$ indicates the syntactic subject and not the morphological flagging, that is, nominative because the marker $=m a$ is used for the subject and the genitive.

Distal demonstrative $\tilde{a}$

Subject in the LHR and in the MC

(80) ã̀ tốfkũ̀mārẽ̀ pàtàsyấhí::

$\begin{array}{lll}{[\tilde{\mathbf{a}}} & \text { ta- } \tilde{\mathrm{o}}-\mathrm{k}-\boldsymbol{\emptyset}-\mathrm{-wa}]=\mathbf{m a}=\mathbf{r e} & \text { pa-tas=yã=hi } \\ \text { DEM.DIST } & \text { MID-lose-K-SBJ3SG-PRS=SBJ=? } & \text { INCL-PRO1=LOC=COP.SBJ3SG.PRS }\end{array}$

'It is with us (i.e. in our generation) that it (the Pesh language) is being lost.'

$\{t x t\}$

Medial demonstrative to?

Genitive in the LHR - Subject in the MC

(81) tó? àwằrí kà?yè?ímà àsìrà énẽpé

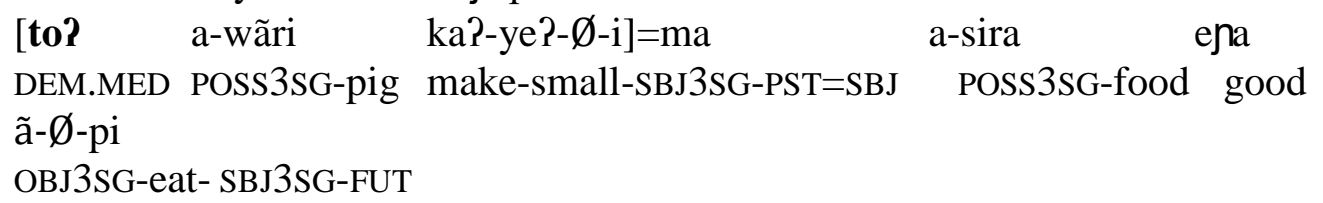

'The one whose sow gave birth will eat well.'

The three demonstrative pronouns, medial to? (81), distal $\tilde{a}(80)$ and proximal $\tilde{l}(82)$, can function as light heads.

Proximal demonstrative $\tilde{l}$

Subject in the LHR - Manner in the MC

(82)

\begin{tabular}{|c|c|c|c|}
\hline$[\tilde{a}=y \tilde{a}$ & $\tilde{\mathbf{I}}$ & $\left.\mathrm{t} \int \mathrm{a}-\mathrm{i}-\mathrm{i}\right]=\mathbf{k a n}$ & $\mathrm{sa}=\mathrm{i}$ \\
\hline DEM.DIST $=$ LOC & DEM.PROX & be_there-SBJ3SG-PST=SIM & rock $=$ COP.SBJ3SG.PRS \\
\hline
\end{tabular}

Light heads are generally demonstratives $(80,81,82)$. The quantifier 'all' (83) and the numeral 'one' (84) can also introduce LHRs but these elements are very infrequent. 
Quantifier krih 'all'

Object in the LHR and in the MC

(83) kèt fá krìh tùhúrímà à̃áfí

$\begin{array}{llll}\text { [ket } \int \mathrm{a} & \text { krih } & \emptyset \text {-tuh-u-ri]=ma } & \emptyset \text {-ã?-a-fi } \\ \text { yesterday } & \text { all } & \text { OBJ3SG-cook-SBJ2-PST=TOP } & \text { OBJ3SG-eat-SBJ1SG-PST.REC }\end{array}$

'I ate all (the things) you cooked yesterday.' $\quad\{\mathrm{txt}\}$

Numeral as 'one'

Subject in the LHR - Instrumental in the MC

(84) kàpákàpá ás tàkàt tùáyó kàtù̃káwá

[kapakapa as ta-ka-tfa- $\emptyset$-wa]=yo katũf-k-a-wa

always one OBJ1-APPL.R-be_there-SBJ3SG-PRS=COM/INS work-K-SBJ1SG-PRS

'I work with the one (machete) that I have always had.' $\{t x t\}$

The light head usually has the role of an argument (or genitive) in the LHR (79-84), but less frequently it can have another role $(85,86)$. In this context, the marker corresponds to the syntactic role of the light head in the LHR.

Medial demonstrative to?

Comitative in the LHR - Object in the MC

(85) tó? tè?kúríyó kàhírtáwá

$\begin{array}{lll}\text { [to? } & \text { te?-k-u-ri=yo] } & \text { ka-hir-a-tV-wa } \\ \text { DEM.MED } & \text { come-K-SBJ2-PST=COM/INS } & \text { OBJ3PL-know-SBJ1SG-NEG-PRS } \\ \text { 'I don't know (that one) with whom you came.' }\{\text { txt }\}\end{array}$

Proximal demonstrative $\tilde{\imath}$

Manner in the LHR - topicalized subject in the MC

(86) ĩ kàtùhúkánmà tàhtétwá

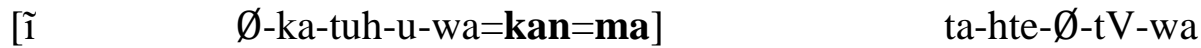

DEM.PROX OBJ3SG-APPL.R-cook-SBJ2-PRS=SIM=TOP OBJ1SG-like-SBJ3SG-NEG-PRS

'I don't like this way you cook it.' $\{$ txt $\}$

For LHRs, the accessibility to different roles is wide: the only role that has not been found is the locative (87a). In example (87b) the combination of the proximal demonstrative and the locative case $\tilde{\imath} y \tilde{a}$ means 'here'. The construction that results in this cases is the headless relative clause in $(87 \mathrm{c})$, which will be discussed in Section 4.2.2.

(87) a. ̃́ t fâúnãtè?kí

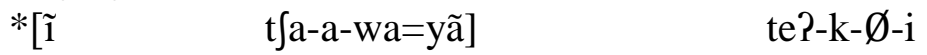

* DEM.PROX be_there-SBJ1SG-PRS=LOC come-K-SBJ3SG-PST

Intended reading: 'He came to the place where I am'

b. ̃́yắ tfâúnãtè?kí

[ $\left.\tilde{1}=y \tilde{a} \quad \mathrm{t} \int \mathrm{a}-\mathrm{a}-\mathrm{wa}=\mathrm{ya}\right] \quad$ te?-k- $\varnothing-\mathrm{i}$

DEM.PROX=LOC be_there-SBJ1SG-PRS=LOC come-K-SBJ3SG-PST

'He came here where I am' 
c. tfàúnãtè?kí

[t $\left.\int a-a-w a=y \tilde{a}\right] \quad$ te?-k- $\varnothing-\mathrm{i}$

be_there-SBJ1SG-PRS=LOC come-K-SBJ3SG-PST

'He came where I am'

Table 8 shows the accessibility to different roles for light-headed RCs.

Table 8. Accessibility to different roles in LHRs

\begin{tabular}{lccccccc}
\hline Strategy & SBJ & $\begin{array}{c}\text { OBJ } \\
\text { (primary/secondary) }\end{array}$ & GEN & INS & COM & MAN & LOC \\
\hline LHRs & $\sqrt{ }$ & $\sqrt{ }$ & $\sqrt{ }$ & $\sqrt{ }$ & $\sqrt{ }$ & $\sqrt{ }$ & $*$ \\
\hline
\end{tabular}

\subsubsection{Headless relative clauses without a light-head or $w h$-expression}

In headless relative clauses without a $w h$-expression or light head ( $\emptyset$-HRs), a case or topic marker occurs in clause-final position. This is a very frequent strategy used for definite-like maximal headless relative clauses. Various types of syntactic role are possible, as shown in (88-94):

Subject in the HR and in the MC

(88) kàpáfkúmà tàyè?í

[kapa $-\mathrm{k}-\varnothing$-wa=ma] ta-ye?-i

speak-K-SBJ3SG-PRS $=\mathrm{SBJ}^{9} \quad$ POSS1-small=COP.SBJ3SG.PRS

'The one who is speaking is my daughter.' $\quad\{t x t\}$

Object in the HR and in the MC

(89) tùhúrímà à̀?áí

[Ø-tuh-u-ri=ma]

$\emptyset$-ã?-a- $\int \mathrm{i}$

OBJ3SG-cook-SBJ2-PST=TOP OBJ3SG-eat-SBJ1SG-PST.REC

'I ate what you cooked.' $\{\mathrm{txt}\}$

Object in the HR and in the MC

(90) jē̄herìrà kàrjāwĩ̀

[Ø-yẽh-er-i=ra] $\emptyset$-ka-er-i=na=wĩ

OBJ3SG-say-SBJ3PL-PST=ACC OBJ3SG-make-SBJ3PL-PST=REP=long_ago

'Long ago, they said that they made what they said.' $\{$ txt $\}$

Comitative in the HR and in the MC

(91) wíPtúpíríyó wí?túrí

[wi?-t-u-pi-ri=yo] wi?-t-u-ri

dance-T-SBJ2-FUT-PST=COM/INS dance-T-SBJ2-PST

'You danced with the one you were going to dance with.' $\quad\{\mathrm{txt}\}$

\footnotetext{
${ }^{9}$ The alignment is subject-accusative as for headed relative clauses and light-headed relative clauses.
} 
Instrumental in the HR - object in the MC

(92) tàyè? kàtû́fkúyó àkìớh kàárí

[ta-ye? katũf-k-i-wa=yo] akiõh Ø-ka-a-ri

POSS1-small work-K-SBJ3SG-PRS=COM/INS edge OBJ3SG-make-SBJ1SG-PST

'I sharpened the one that my son uses to work with.' $\{\mathrm{txt}\}$

Manner in the HR - object in the MC

(93) kàtùhúkán tàhtétwá

[Ø-ka-tuh-u-wa=kan] ta-hte- Ø-tV-wa

OBJ3SG-APPL.R-cook-SBJ2-PRS=SIM OBJ1SG-like-SBJ3SG-NEG-PRS

'I don't like the way you cook it.' $\quad\{\mathrm{txt}\}$

Locative in the HR - object in the MC

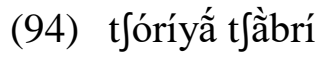

[t $\left.\int \mathrm{a}-\mathrm{u}-\mathrm{ri}=\mathbf{y} \tilde{\mathbf{a}}\right] \quad \emptyset$-t $\int \tilde{\mathrm{a}}-\mathrm{ber}-\mathrm{i}$

be_there-SBJ2-PST=LOC OBJ3SG-See-SBJ1PL.EXCL-PST

'We saw where you were born.' $\{$ txt $\}$

The accessibility to different roles is different for $\emptyset$-HRs than LHRs. As with the examples in (87), the locative is not available for LHRs, but it is for Ø-HRs (94). Conversely, the genitive is available for LHRs but not for $\emptyset$-HRs (95a). This is probably due to the fact that in $\emptyset$-HRs, the possessor cannot be expressed. For this case, my informants proposed a LHR (95b).

(95) a. *àkákì ờ:nímà carbonã àsùwáyó nềtfúá

\begin{tabular}{|c|c|c|}
\hline [a-kaki & $\tilde{o}-n-\emptyset-i]=m a$ & Carbon=yã \\
\hline POS & sleep-DUR-SBJ3SG-PST=SBJ & $=\mathrm{LOC}$ \\
\hline =yo & nã-t $\int a-\varnothing-$ & \\
\hline r-granams & COM/INS & RS \\
\hline
\end{tabular}

Intended reading: '(The one) whose mother died is going to live in Carbon with his grandmother.'

b. tó? àkákì ồ:nímà carbonã àsùwáyó nẽ̀tfúá
[to?
a-kaki
ô-n- $\varnothing-i]=m a$
Carbon=yã
DEM.MED
POSS3SG-mother sleep-DUR-SBJ3SG-PST=SBJ
Carbon $=\mathrm{LOC}$
a-suwa =yo
nã-t $a-\emptyset$-wa
POSS3SG-grandmother=COM/INS go-be_there-SBJ3SG-PRS

'The one whose mother died is going to live in Carbon with his grandmother.'

Table 9 shows the accessibility to different roles for $\emptyset$-RCs.

Table 9. Accessibility to different roles / Ø-RCs

\begin{tabular}{lccccccc}
\hline Strategy & SBJ & $\begin{array}{c}\text { OBJ } \\
\text { (primary/secondary) }\end{array}$ & GEN & INS & COM & MAN & LOC \\
\hline$\varnothing$-HRs & $\sqrt{ }$ & $\sqrt{ }$ & $*$ & $\sqrt{ }$ & $\sqrt{ }$ & $\sqrt{ }$ & $\sqrt{ }$ \\
\hline
\end{tabular}




\section{Conclusion}

Pesh possesses two types of relative construction: the first type uses a wh-expression to the left edge and a subordinator to the right edge. This construction is used for maximal, existential and free choice FRs, and also for headed relative clauses with a $w h$-word. The second type corresponds to headless relative clauses that lack a $w h$-expression, in which a case the topic marker is found to the right edge.

Tables 8 and 9 compare the two types with respect to the accessibility to different roles. The higher frequency of the second type is probably due to the fact that it is coherent with the most frequent constructions used in headed relative clauses that lack a wh-expression.

Table 10. Type 1: Accessibility to roles (using a wh-expression)

\begin{tabular}{|c|c|c|c|c|c|c|c|c|c|c|c|}
\hline & $\begin{array}{l}\text { Cons- } \\
\text { tructions }\end{array}$ & SBJ & $\begin{array}{c}\text { OBJ } \\
\text { (primary/secondary) }\end{array}$ & GEN & INS & $\mathrm{COM}$ & MAN & LOC & QUANT & REAS & TEMP \\
\hline \multicolumn{2}{|c|}{ Headed RCs } & $*$ & $*$ & $*$ & $*$ & $*$ & $*$ & $\sqrt{ }$ & $*$ & $*$ & $*$ \\
\hline & Max. & $*$ & $*$ & $*$ & * & $*$ & $*$ & $\sqrt{ }$ & $*$ & $*$ & * \\
\hline \multirow[t]{2}{*}{ FRs } & Ex. & $\sqrt{ }$ & $\sqrt{ }$ & $\sqrt{ }$ & $\sqrt{ }$ & $\sqrt{ }$ & $\sqrt{ }$ & $\sqrt{ }$ & $\sqrt{ }$ & $*$ & $\sqrt{ }$ \\
\hline & $\mathrm{FC}$ & $\sqrt{ }$ & $\sqrt{ }$ & $\sqrt{ }$ & $\sqrt{ }$ & $\sqrt{ }$ & $\mathrm{n} / \mathrm{a}$ & $\sqrt{ }$ & $\sqrt{ }$ & $*$ & $* / \sqrt{ }$ \\
\hline
\end{tabular}

Table 11. Type 2: Accessibility to roles (without a wh-expression)

\begin{tabular}{lccccccc}
\hline Constructions & SBJ & $\begin{array}{c}\text { OBJ } \\
\text { (primary/secondary) }\end{array}$ & GEN & INS & COM & MAN & LOC \\
\hline Headed RCs & $\sqrt{ }$ & $\sqrt{ }$ & $\sqrt{ }$ & $\sqrt{ }$ & $\sqrt{ }$ & $\sqrt{ }$ & $\sqrt{ }$ \\
\hline LHRs & $\sqrt{ }$ & $\sqrt{ }$ & $\sqrt{ }$ & $\sqrt{ }$ & $\sqrt{ }$ & $\sqrt{ }$ & $*$ \\
\hline$\emptyset$-HRs & $\sqrt{ }$ & $\sqrt{ }$ & $*$ & $\sqrt{ }$ & $\sqrt{ }$ & $\sqrt{ }$ & $\sqrt{ }$ \\
\hline
\end{tabular}

The second type is the most frequent and is used for light-headed relative clauses, headless RCs without a $w h$-expression and for headed relative clauses.

\section{Acknowledgments}

The data presented here are part of the Major Documentation Project MDP0276, "A cross-varietal documentation and description of Pesh, a Chibchan language of Honduras" (https://elar.soas.ac.uk/Collection/MPI1050997) funded by HRELP (the Hans Rausing Endangered Languages Programme). I am greatly indebted to the HRELP for their financial support. I extend my deepest thanks to all my informants: this research would not have been possible without the support of Juana Hernández Duarte, Nimer López Garcia, Danilo Lugo Mendoza, Ángel Martínez Torres, Hernán Martínez Escobar, and all our Pesh hosts. Special thanks for their insightful comments are due to: Ivano Caponigro, Roberto Zavala, Harold Torrence, Enrique Palancar and Judith Aissen, the two reviewers and the participants in the UCMexus/Conacyt "Headless Relative Clauses" workshop in San Cristobal de las Casas in May-June 2018.

\section{References}

Bybee Joan L. 1985. Morphology: A Study of the Relation Between Meaning and Form. Amsterdam: John Benjamins.

Caponigro, Ivano. 2003. Free not to ask. PhD thesis, University of California, Los Angeles. 
Chamoreau, Claudine. 2017. A preliminary grammatical sketch. ELDP report. August 2017 (ms. $158 \mathrm{pp}$.).

Chamoreau, Claudine. 2018. Constituent order flexibility, differential case marking, and focus in Pesh. Invited talk at the Workshop "OV basic word order correlates and Information Structure", LABEX EFL-INALCO-SeDyL, Paris, December 6-7, 2018.

Chamoreau, Claudine. Forthcoming.a. Overt topic marking and discourse coherence in Pesh: Between correlation and tension. Anthropological Linguistics.

Chamoreau, Claudine. Forthcoming.b. Restrictive headed relative constructions in Pesh. In E. Palancar, R. Zavala Maldonado, and C. Chamoreau (eds), Relative clauses in Mesoamerica and beyond.

Citko, Barbara. 2004. On headed, headless, and light-headed relatives. Natural Language and Linguistic Theory 22: 95-126.

Comrie, Bernard. 1989 [1981]. Relative clauses. In Bernard Comrie (ed.), Language universals and linguistic typology. Syntax and morphology, 2nd edition, 138-164. Oxford: Blackwell.

Constenla Umaña, Adolfo. 2012. The Chibchan languages. In L. Campbell and V. Grondona (eds), The indigenous languages of South America: A comprehensive guide, Vol. 2, 391-437. Berlin: Mouton de Gruyter.

Conzemius, E. 1928. Los Indios Paya de Honduras. Estudio geográfico, histórico, etnográfico, y lingüístico. Journal de la Société des Américanistes 20: 253-360.

Creissels, Denis. 2017. Similarity, suitability, and non-epistemic modalities (volitionality, ability, and obligation). In M. Vanhove and Y. Treis (eds), Similative and Equative Constructions, 7989. Amsterdam: John Benjamins.

Frank, Paul. 1990. Ika syntax. (Studies in the Languages of Colombia, 1.) Arlington: Summer Institute of Linguistics and The University of Texas at Arlington.

Holt, Dennis. 1999. Pech (Paya). Munich: Lincom Europa.

Quesada, Diego. 2007. The Chibchan languages. Costa Rica: Editorial Tecnológica de Costa Rica. Wilson, Jack. 1984. Relative clauses in Bribri. Estudios de Lingüística Chibcha 3: 179-199. 